\title{
Article \\ Comparative Transcriptomics and Gene Knockout Reveal Virulence Factors of Arthrinium phaeospermum in Bambusa pervariabilis $\times$ Dendrocalamopsis grandis
}

\author{
Xinmei Fang ${ }^{1}$, Peng Yan ${ }^{1}$, Mingmin Guan ${ }^{1}$, Shan Han ${ }^{1}$, Tianmin Qiao ${ }^{2}$, Tiantian Lin ${ }^{1}$, Tianhui Zhu ${ }^{1}$ \\ and Shujiang $\mathrm{Li}^{1,2, * \mathbb{C}}$ \\ 1 College of Forestry, Sichuan Agricultural University, Chengdu 611130, China; \\ 2019104009@stu.sicau.edu.cn (X.F.); 201707355@stu.sicau.edu.cn (P.Y.); lilin3@stu.sicau.edu (M.G.); \\ 13722@sicau.edu.cn (S.H.); tlin@sicau.edu.cn (T.L.); 10627@sicau.edu.cn (T.Z.) \\ 2 National Forestry and Grassland Administration Key Laboratory of Forest Resources Conservation and \\ Ecological Safety on the Upper Reaches of the Yangtze River, Chengdu 611130, China; 11470@sicau.edu.cn \\ * Correspondence: 14087@sicau.edu.cn; Tel.: +86-186-0835-7494
}

check for updates

Citation: Fang, X.; Yan, P.; Guan, M.; Han, S.; Qiao, T.; Lin, T.; Zhu, T.; Li, S Comparative Transcriptomics and Gene Knockout Reveal Virulence Factors of Arthrinium phaeospermum in Bambusa pervariabilis $\times$ Dendrocalamopsis grandis. J. Fungi 2021, 7, 1001. https:// doi.org/10.3390/jof7121001

Academic Editor:

Pierre-Emmanuel Courty

Received: 27 September 2021

Accepted: 19 November 2021

Published: 24 November 2021

Publisher's Note: MDPI stays neutral with regard to jurisdictional claims in published maps and institutional affiliations.

Copyright: (C) 2021 by the authors Licensee MDPI, Basel, Switzerland. This article is an open access article distributed under the terms and conditions of the Creative Commons Attribution (CC BY) license (https:// creativecommons.org/licenses/by/ $4.0 /)$.

\begin{abstract}
Arthrinium phaeospermum can cause branch wilting of Bambusa pervariabilis $\times$ Dendrocalamopsis grandis, causing great economic losses and ecological damage. A. phaeospermum was sequenced in sterile deionized water (CK), rice tissue (T1) and B. pervariabilis $\times D$. grandis (T2) fluid by RNASeq, and the function of $C t f 1 \beta 1$ and $C t f 1 \beta 2$ was verified by gene knockout. There were 424, 471 and 396 differentially expressed genes between the T2 and CK, T2 and T1, and CK and T1 groups, respectively. Thirty DEGs had verified the change in expression by fluorescent quantitative PCR. Twenty-nine DEGs were the same as the expression level in RNA-Seq. In addition, $\triangle \mathrm{ApCtf1} \beta 1$ and $\triangle \mathrm{ApCtf1} \beta 2$ showed weaker virulence by gene knockout, and the complementary strains $\mathrm{Ctf} 1 \beta 1$ and $\mathrm{Ctf} 1 \beta 2$ showed the same virulence as the wild-type strains. Relative growth inhibition of $\triangle \mathrm{ApCtf1} \beta 1$ and $\triangle$ ApCtf1 $\beta$ was significantly decreased by $21.4 \%$ and $19.2 \%$, respectively, by adding $\mathrm{H}_{2} \mathrm{O}_{2}$ compared to the estimates from the wild-type strain and decreased by $25 \%$ and $19.4 \%$, respectively, by adding Congo red. The disease index of $B$. pervariabilis $\times D$. grandis infected by two mutants was significantly lower than that of wild type. This suggested that $C t f 1 \beta$ genes are required for the stress response and virulence of $A$. phaeospermum.
\end{abstract}

Keywords: A. phaeospermum; $B$. pervariabilis $\times$ D. grandis; differentially expressed genes; cutinase transcription factor 1 beta; gene function

\section{Introduction}

Bambusa pervariabilis $\times$ Dendrocalamopsis grandis (hybrid bamboo), a kind of hybrid bamboo, is a vital renewable resource and is known as the "second forest" [1]. This hybrid bamboo has strong adaptability, cold resistance and drought resistance, a thick culm arm and uniform fiber length and is a good raw material for papermaking. Hybrid bamboo is dual-purpose and can be used for bamboo shoots and materials [2]. However, in recent years, hybrid bamboo shoot blight caused by Arthrinium phaeospermum has occurred in a large area of the Yangtze River basin, resulting in plant death and huge economic losses, threatening the construction of ecological barriers. A. phaeospermum is a plant pathogenic fungus distributed all over the world and a generalist with a broad range of host species [3]. In addition to B. pervariabilis $\times D$. grandis [4], its host plants also include cowpea, garden pea [5], sugarcane [6], Phyllostachys prominens [7,8], new olive [9], Phyllostachys viridis [10], etc.

Previous research on the shoot blight of $B$. pervariabilis $\times D$. grandis caused by $A$. phaeospermum indicated that the AP protein toxin can damage the mitochondrial membrane of host $B$. pervariabilis $\times D$. grandis shoots and inhibit respiration [11]. At the same 
time, the AP protein toxin affected the activities of defense enzymes such as superoxide dismutase, peroxidase, phenylalanine aminonyase, polyphenol oxidase, chitinase and $\beta-1$, 3 glucanase of $B$. pervariabilis $\times D$. grandis [12], and its binding sites are proteins located on the cytoplasmic membrane of host plants. The toxin protein purified from the fermentation broth of A. phaeospermum by column chromatography and anion exchange chromatography showed strong virulence, different from the previously known pathogenic factors, such as arthrichitin and arthrinic acid, isolated from human skin diseases by Vijayakumar et al. [13] and Bloor [14]. Previous studies have found that the pathogenic active substances produced by the same fungus in different hosts and under different conditions are different $[15,16]$. In the biological control of this disease, we found that the chloramphenicol-resistant mutant of Pseudomonas aeruginosa ZB27 had a favorable effect on B. pervariabilis $\times D$. grandis blight [17]. In addition to research on the occurrence and damage of the disease, the isolation mechanism of pathogenic toxins and the biocontrol mechanism of antagonistic microorganisms, we also tried to explore the infection mechanism of A. phaeospermum and the defense pathway of $B$. pervariabilis $\times D$. grandis at the molecular level. Based on the whole genome information of $A$. phaeospermum [3], significant differences were found in the proteome level of $B$. pervariabilis $\times D$. grandis after pathogen infection, among which the differential proteins were enriched mainly in the biological process and cell components [18]. There were also significant differences in the proteome and transcriptome levels of $B$. pervariabilis $\times D$. grandis induced by inactivated protein toxin, among which the differentially abundant proteins were mainly enriched in biological processes and cell components. At the same time, the differentially expressed genes were involved mainly in lignin and phytoprotein synthesis, tetrapyrrole synthesis, redox reactions, photosynthesis, and other processes $[19,20]$.

However, the interaction between host plants and fungal pathogens is well known to be essentially a coevolutionary mechanism. Pathogens invade host plants and then activate plant pathogen-associated molecular patterns-triggered immunity (PTI) due to the recognition of PAMPs of pathogenic fungi, including local cell wall reinforcement, induction of defense genes, secretion of chitinase, production of reactive oxygen species and production and release of antimicrobial compounds. To inhibit PTI, pathogens produce effectors to escape the recognition of immune receptors and induce the production of resistant proteins in plants to trigger ETI. Therefore, when pathogens interact with host plants, in addition to the metabolic changes in the host plants, the gene expression in the pathogens will also be significantly different [21-24].

In recent years, with the in-depth study of the interaction between pathogens and host plants and the rapid development of sequencing technology, RNA-seq has been widely used to study the mechanism of plant pathogen interactions. At present, RNA-seq in the study of plant pathogen interactions focuses mainly on screening host plant disease resistance genes and disease resistance metabolic pathways, which provides a theoretical basis for plant disease resistance mechanisms. For example, RNA-seq can be used in rice [25], Arabidopsis thaliana [26], tomato [27] and other host plants. However, RNA-seq is rarely used to study pathogens in the interaction process; in particular, the interaction between $A$. phaeospermum and $B$. pervariabilis $\times D$. grandis has not been reported during host infection. It is necessary to screen some genes related to $A$. phaeospermum infection and pathogenicity by transcriptome analysis, but the specific functions of these candidate genes during infection are not clear. Gene knockout is an important means to study gene function. At present, the function of key genes in many fungi has been confirmed, including Beauveria bassiana [28], Aspergillus niger [29], and Trichoderma harzianum [30]. This paper sequenced and compared the transcriptome of fungi cultured on PDA medium, PDA medium containing $10 \%$ rice tissue fluid and PDA medium containing $10 \%$ B. pervariabilis $\times D$. grandis tissue and verified the genes with significant differences by fluorescent quantitative PCR. Finally, we explored gene function by gene knockout. The purpose of this study was to provide reliable reference data for further study on the pathogenic mechanism of $A$. phaeospermum and the disease resistance mechanism of B. pervariabilis $\times D$. grandis. 


\section{Materials and Methods}

\subsection{Meterials}

Microorganism: A. phaeospermum was isolated by tissue isolation method [31] from diseased B. pervariabilis $\times D$. grandis, the accession number of $A$. phaeospermum ITS in NCBI database is OK626768. The isolate was stored in China Forestry Culture Collection Center, numbered cfcc 86860 (http:/ / www.cfcc-caf.org.cn/, accessed on 6 April 2007).

Plant tissue sample: One-year-old B. pervariabilis $\times D$. grandis (bamboo seedlings were purchased from Shuyang Qichen Bamboo Seedling Co., Ltd., Suqian, China) were planted in the bamboo-growing areas of reclaimed farmland $\left(103^{\circ} 01^{\prime} \mathrm{N}, 29^{\circ} 54^{\prime} \mathrm{E}\right)$ in Sichuan, China. The study area was at an altitude of $515.98 \mathrm{~m}$ with annual temperatures of $6.8^{\circ} \mathrm{C}$ to $26.1^{\circ} \mathrm{C}$ and annual precipitation of $1300-1700 \mathrm{~mm}$. Pathogenicity test sample: One-yearold B. pervariabilis $\times D$. grandis were planted in greenhouse of Chengdu, Sichuan, China at a temperature of $25^{\circ} \mathrm{C}$.

\subsection{Methods}

\subsubsection{Preparation of Transcriptome Sequencing Mycelia}

The method of Andrade et al. [32] and Jiang et al. [33] was used to obtain sterile $B$. pervariabilis $\times D$. grandis plant tissue fluid. Young shoots of $B$. pervariabilis $\times D$. grandis were cut to $20 \mathrm{~g}$, disinfected with $1.5 \%$ sodium hypochlorite for $1 \mathrm{~min}$, disinfected with $75 \%$ alcohol for $3 \mathrm{~min}$, washed with sterile deionized water three times, ground with $20 \mathrm{~mL}$ sterile deionized water and filtered with sterile gauze. The filtrate was centrifuged in a $20 \mathrm{~mL}$ centrifugal tube at $4{ }^{\circ} \mathrm{C}$ and $7000 \mathrm{rpm}$ for $10 \mathrm{~min}$. The supernatant was transferred to a new $20 \mathrm{~mL}$ centrifugal tube and centrifuged four times. Finally, the supernatant was removed by using a sterile $0.22-\mu \mathrm{m}$ bacterial filter. The tissue liquid of B. pervariabilis $\times D$. grandis was obtained and stored at $-20^{\circ} \mathrm{C}$ for subsequent experiments. The method of Andrade et al. [31] was also used to obtain sterile rice plant tissue fluid.

Mycelium treatment. Two milliliters of sterile deionized water, sterile rice tissue fluid and sterile B. pervariabilis $\times D$. grandis were placed on PDA medium (Haibo Biotechnology Co., Ltd., Qingdao, China), spread evenly with a coater and placed on a clean worktable for future use. A. phaeospermum was inoculated into PDA medium coated with $2 \mathrm{~mL}$ sterile deionized water (CK), PDRA medium coated with $2 \mathrm{~mL}$ sterile rice tissue fluid (T1) and PDHA medium coated with $2 \mathrm{~mL}$ sterile B. pervariabilis $\times$ D. grandis tissue fluid (T2). Each treatment was repeated 3 times, cultured in a $25^{\circ} \mathrm{C}$ incubator for 7 days and preserved.

\subsubsection{Extraction and Quality Detection of A. phaeospermum RNA}

The phenol chloroform method [34] was used to extract total RNA from A. phaeospermum grown in sterile deionized water, sterile rice tissue fluid and sterile $B$. pervariabilis $\times D$. grandis tissue fluid. Then, the genomic DNA was removed by DNase, RNase inhibitor (Takara, Dalian, China) and other reagents. Agarose gel electrophoresis, a Nanodrop microspectrophotometer (NANODROP, ThermoFisher Scientific-CN, Shanghai, China) and an Agilent 2100 bioanalyzer were used to test the total RNA integrity, purity and quality [35], respectively. If the ratio of 28S: $18 \mathrm{~S}$ rRNA was 2:1, the RNA integrity was good. Among the total RNA purity tests, the A260/ A280 ratio was optimal between 1.8 and 2.0.

\subsection{3. cDNA Preparation and Illumina Sequencing}

PrimeScriptTM Double Strand cDNA Synthesis Kit (TaKaRa) was used to construct the cDNA library of A. phaeospermum. Poly(A) + RNA was isolated from aggregated RNA samples by using oligonucleotide (dT) beads [36]. Fragmentation buffer was added to interrupt the expression of mRNA: the short fragments were used as templates, and random hexamer primers were used to form the first strand of the cDNA. Then, the second strand of cDNA was synthesized by buffer, dNTPs, RNase $\mathrm{H}$ and DNA polymerase. The doublestranded cDNA was purified, and at the end of the repair, poly(A) and joints were added to establish a cDNA library [37]. The cDNA library was sequenced on an Illumina HiSeq2000 platform by Guangzhou Gene Denovo Biotechnology Co., Ltd. (Guangzhou, China). 


\subsubsection{Sequence Data Filtering, De Novo Assembly and Contig Annotation}

Before assembly, the low-quality sequences from raw reads were removed, including sequences with ambiguous bases (denoted with $>10 \%$ ' $\mathrm{N}$ ' in the sequence trace), lowquality reads (the rate of reads with a quality value $\leq 5$ was more than $50 \%$ ) and reads with adaptors. Transcriptome de novo assembly was carried out with the short read assembly program Trinity (Version: 2.1.1. Parameter: $\mathrm{Kmer}$ size $=31$, Kmer cov $=7$ ) [38]. TGICL software was used to cluster and remove redundant representative sequences. TGICL version number: tgicl-2.1: All parameters were default parameters, $-p=94$ (minimum percent identity for overlaps), $-1=40$ (minimum overlap length), and $-\mathrm{v}=30$ (maximum length of unmatched overhangs). We assembled nine samples (CK-1, CK-2, CK-3, T1-1, T1-2, T1-3, T2-1, T2-2 and T2-3) to obtain contigs and then used TGICL to cluster the contigs to remove redundancy. All annotations were performed on the merged contig set. To obtain GO information for the contig, first, the contig sequence was aligned to the protein database $\mathrm{Nr}$ (evalue $<0.00001$ ) by blastx, and the protein with the highest sequence similarity to a given contig was obtained; thus, the $\mathrm{Nr}$ annotation information of the contig was obtained. Subsequently, according to $\mathrm{Nr}$ annotation information, contig $\mathrm{GO}$ annotation information was obtained using Blast2GO software [39]. The merged contig set function was annotated to the following databases by using BLAST+ (Version: 21:2.6.0+/TH2: 2.5.0+. Parameter: -evalue $10^{-5}$. http://www.ncbi.nlm.nih.gov/BLAST/, accessed on 10 November 2018) [40]: the Gene Ontology database (GO) [41] (http:/ / www.geneontology. $\mathrm{org} /$, accessed on 10 November 2018); the Kyoto Encyclopedia of Genes and Genomes (KEGG) [42] (http:/ / www.genome.jp/kegg/, accessed on 10 November 2018); the Clusters of Protein Homology (KOG) [43] (http://www.ncbi.nlm.nih.gov/KOG/, accessed on 10 November 2018); the NCBI Non-Redundant Protein Sequence database (Nr) [44] (ftp: / / ftp.ncbi.nih.gov/blast/db/, accessed on 10 November 2018); and a manually annotated, nonredundant protein sequence database (Swiss-Prot) [45] (http://www.uniprot.org/, accessed on 10 November 2018). After obtaining GO annotations for each contig, we used WEGO software [46] to classify and count all contigs and understand the merged contig set function distribution characteristics in a macroscopic view.

\subsubsection{Analysis of Differentially Expressed Genes under Different Treatment Condition}

The differential expression of pathogenic fungi in sterile deionized water (CK), sterile rice tissue fluid (T1) and sterile B. pervariabilis $\times$ D. grandis tissue fluid (T2) was analyzed. First, RSEM software [47] (Version 1.2.19) was used to align by calling bowtie2 to obtain the read count quantitatively. Then, the software package edgeR (http:/ /www.bioconductor. org/packages/release/bioc/html/edgeR.html, accessed on 10 November 2018) based on $\mathrm{R}$ language was used for different analyses. Genes with significant differences in expression were defined as having a false discovery rate (FDR) $<0.05$ and $2 \log \mathrm{FC}>2$. GO (Ashburner et al., 2000) [41] functional analysis and KEGG [42] pathway analysis of differential gene DEGs were carried out to search for virulence genes.

\subsubsection{Real-Time Fluorescence Quantitative PCR Verification}

Firstly, we selected the genes with high differential multiples in several treatment groups, including up-regulated differential genes and down-regulated differential genes. In addition, 30 candidate genes were screened by combining the gene function annotation information in the database. We selected GAPDH and Actin as internal reference genes in RT-PCR analysis to determine whether RT-PCR with GAPDH and Actin as reference genes is consistent with transcriptional sequencing results, so as to verify the reliability of transcriptome sequencing data. Primer Premier 5.0 software was used to design fluorescence quantitative PCR primers using CDS regions of the internal reference gene GAPDH and 30 candidate genes (Table 1 . There were 10 candidate genes in the Ck-vs-T1 treatment group, 10 candidate genes in the $\mathrm{Ck}$-vs-T2 treatment group and 10 candidate genes in the T1-vs-T2 treatment group) as templates. The primer sequences of 30 candidate DEGs and internal reference genes are shown in Table 2 . The length of the primer was $20-25 \mathrm{bp}$, and 
the length of the target amplification band was 100-200 bp. In this experiment, fluorescence quantitative polymerase chain reaction (CFX96-Real-Time System, Bio-Rad, Hercules, CA, USA) was used to quantify the changes in the expression of thirty candidate DEGs in sterile deionized water, rice tissue fluid and sterile B. pervariabilis $\times D$. grandis tissue fluid. The qPCR system consisted of the following: $10 \mu \mathrm{L}$ Mix (TSINGKE, Beijing, China), $7.4 \mu \mathrm{L}$ $\mathrm{ddH}_{2} \mathrm{O}, \mathrm{F} / \mathrm{R} 0.8 \mu \mathrm{L}$, and $1 \mu \mathrm{L}$ cDNA (CK/T2). The qPCR was as follows: $95^{\circ} \mathrm{C}$ for $1 \mathrm{~min}$, $95^{\circ} \mathrm{C}$ for $30 \mathrm{~s}$ and $60^{\circ} \mathrm{C}$ for $15 \mathrm{~s}$. Forty cycles were repeated from the second step to the third step, and the dissolution curve was added at the final step. Each group of qPCR was repeated three times, and the average value was calculated. GAPDH was used as an internal reference gene to detect the expression changes of 30 candidate pathogenic genes in 3 different treatment groups. Data were analyzed by the $2^{-\triangle \Delta \mathrm{Ct}}$ method [48].

Table 1. Thirty Candidate validation genes.

\begin{tabular}{|c|c|c|c|}
\hline Comparison Group & Gene Name & Log2 Ratio & Description \\
\hline \multirow{10}{*}{ CK-VS-T1 } & $\operatorname{Cos} 1 P$ & 9.956230937 & cytochrome oxidase subunit 1, partial [Brevilegnia unisperma] \\
\hline & Ench & -11.38168714 & endochitinase [Amphiamblys sp. WSBS2006] \\
\hline & $\mathrm{La} 4 \mathrm{H}$ & -5.228792158 & leukotriene A-4 hydrolase/aminopeptidase \\
\hline & Ench2 & -10.25223177 & endochitinase [Amphiamblys sp. WSBS2006] \\
\hline & HydP & -5.849553363 & hydrolase, partial [Mucor ambiguus] \\
\hline & HydP1 & -5.423936695 & hydrolase, partial [Mucor ambiguus] \\
\hline & $\mathrm{CatH}$ & -5.21899521 & cathepsin H [Saprolegnia diclina VS20] \\
\hline & abhyd & -5.16654726 & alpha/beta hydrolase [Magnaporthe oryzae 70-15] \\
\hline & Cal & -5.003422577 & Calmodulin [Phytophthora nicotianae] \\
\hline & Inv & -4.361126768 & Inversin [Phytophthora nicotianae] \\
\hline \multirow{10}{*}{ CK-VS-T2 } & Ctf1b & 1.16472 & Cutinase transcription factor 1 beta \\
\hline & Fstfd & 4.66024 & Fungal specific transcription factor domain \\
\hline & $E-1,3-b g$ & 1.60198 & Endo-1,3(4)-beta-glucanase \\
\hline & Gh & 1.926701059 & glycoside hydrolase [Stagonospora sp. SRC1lsM3a] \\
\hline & Ghf43P & 2.046533818 & glycoside hydrolase family 43 protein [Trichoderma atroviride] \\
\hline & Ghf 28 & 3.242824341 & glycosyl hydrolase family 28 [Colletotrichum incanum] \\
\hline & Ghf $62 P$ & 3.263709993 & glycoside hydrolase family 62 protein [Schizophyllum commune] \\
\hline & Hyd & -9.113389998 & hydrophobin [Trichoderma atroviride IMI 206040] \\
\hline & Pep & -6.728250664 & permease, partial [Mucor ambiguus] \\
\hline & LaipF & -6.542070296 & Low affinity iron permease, Fet4 [Sporothrix insectorum] \\
\hline \multirow{10}{*}{ T1-VS-T2 } & $C t f 1 b$ & 1.143966714 & Cutinase transcription factor 1 beta \\
\hline & Fstfd & 5.178921385 & Fungal specific transcription factor domain \\
\hline & Gh & 1.674955343 & glycoside hydrolase [Stagonospora sp. SRC1lsM3a] \\
\hline & Ghf62P & 3.240379576 & glycoside hydrolase family 62 protein [Schizophyllum commune] \\
\hline & Ghf $43 P$ & 2.798082794 & glycoside hydrolase family 43 protein [Trichoderma atroviride] \\
\hline & Ghf28 & 3.368988569 & glycosyl hydrolase family 28 [Colletotrichum incanum] \\
\hline & HydP & 9.935115927 & hydrolase, partial [Mucor ambiguus] \\
\hline & Pc22g & -3.307249137 & Pc22g21720 [Penicillium rubens Wisconsin 54-1255] \\
\hline & Hyp $\stackrel{\circ}{P}$ & -3.878218123 & MFS transporter [Purpureocillium lilacinum] \\
\hline & MFSt & -3.222620978 & hypothetical protein NECHADRAFT [Nectria haematococca] \\
\hline
\end{tabular}

Table 2. Thirty Candidate validation genes and reference gene Primer pair information.

\begin{tabular}{|c|c|c|}
\hline Comparison Group & Primer Name & Primer Sequence $5^{\prime}-3^{\prime}$ \\
\hline \multirow{11}{*}{ CK-VS-T2 } & GAPDH & ATGGAGAAGGCTGGGGCTCATTTGC; GATGACCСТTTTGGCTCСССССТGC \\
\hline & Unigene0001578 & ATGGAGAAGGCTGGGGCTCATTTGC; GATGACCCTTTTGGCTCCССCCTGC \\
\hline & Unigene0004220 & ACGAACAGGATACAGGCGACA; CTGAGGTCCAAATAACGAGATGAA \\
\hline & Unigene0004974 & CAGGCGGTTTGGAACTCGT; TGCCATATCCATCCTGCGTC \\
\hline & Unigene0005793 & GCTACTGGCACGACATCGGAT; TCTAGTGGAGTGACAGCAAACGA \\
\hline & Unigene0005693 & ATGTCGGTGGCTGGGTTGA; CCCCTTTTGAGGCGCTGTAT \\
\hline & Unigene0009373 & TTGAGAATGTCTGGTTGCTGAATG: GCGCAGGTTGAGGAGTTGATGT \\
\hline & Unigene0001633 & CGGCAACTTCCCTGGTAGCT; GCCTGGCACGCTATACACCT \\
\hline & Unigene0004295 & TGCTGCTCTACССТСGTTCTTG; CAATAGCCGTCTGGCAAAGGA \\
\hline & Unigene0005088 & GCTACAGATCGTCGCCTTGG; GCTAATACCGCATACGCCCTAC \\
\hline & Unigene0008572 & ССТACACTGGTCTCATCGGTTTC; GCTGGTAATCCTGCTCCATAAGA \\
\hline
\end{tabular}


Table 2. Cont.

\begin{tabular}{|c|c|c|}
\hline Comparison Group & Primer Name & Primer Sequence $5^{\prime}-3^{\prime}$ \\
\hline \multirow{10}{*}{ T1-VS-T2 } & Unigene0001578 & ATGGAGAAGGCTGGGGCTCATTTGC; GATGACCCTTTTGGCTCCССССTGC \\
\hline & Unigene0004220 & ACGAACAGGATACAGGCGACA; CTGAGGTCCAAATAACGAGATGAA \\
\hline & Unigene0005793 & GCTACTGGCACGACATCGGAT; TCTAGTGGAGTGACAGCAAACGA \\
\hline & Unigene0001633 & CGGCAACTTCCCTGGTAGCT; GCCTGGCACGCTATACACCT \\
\hline & Unigene0005693 & ATGTCGGTGGCTGGGTTGA; CCCCTTTTGAGGCGCTGTAT \\
\hline & Unigene0009373 & TTGAGAATGTCTGGTTGCTGAATG; GCGCAGGTTGAGGAGTTGATGT \\
\hline & Unigene0001003 & TCTAAACCCAACTCACGTACCACTT; AACAGGCTGATGACTCCCAAGA \\
\hline & Unigene0005927 & GGCTTTGCCATCCACCACA; GCAATGAAGAGGAGGTAGTCGC \\
\hline & Unigene0007158 & AGGATCGCAATGTGGAAGGC; GGTTGAGGGAAGAGTTTGAGGC \\
\hline & Unigene0007851 & GCAAGAGTCGCACGCAGAA; GCAGGTAAAGCCACAGTCCATAT \\
\hline \multirow{10}{*}{ CK-VS-T1 } & Unigene0006182 & TGCCATAACCCAATACCAAACG; TGTTGAGGTTGCGGTCTGTTAGT \\
\hline & Unigene0000037 & GAGTTCAGCCACGCCATCAC; CATTCCCGCTTCGACTTTGTT \\
\hline & Unigene0000618 & AGAGGAGAAGAACGCCGAGGT; CAATTTCGCCCACAAAGAGCT \\
\hline & Unigene0000640 & TCCAGGCAAGAACTACTACGGTC; CCTTCCAGAACCAGAAAGCAGT \\
\hline & Unigene0000947 & GCTTCTTCGCCTCCCACCTA; CGCTGTCTCGACAATGCACC \\
\hline & Unigene0000948 & ATGCTTTCAGCGTTTATCCCTT; CGTGAGACAGTTCGGTCCCTAT \\
\hline & Unigene0005250 & TTCCGCTTTAAGGTGTTCATGG; CAGGTCGCCGTAGTGGTTCA \\
\hline & Unigene0006199 & CTAGGCTCGTCACGTTTGCG; AACTGCTCCGGTTTGATGATATG \\
\hline & Unigene0000783 & TGGCTGATCAACTGACTGAGGAA; GCCCAGTTCCTTGGTGGTGAT \\
\hline & Unigene0004166 & CGAAGCGCCAAGATTAAGGA; CACTGCCCTCACCGTCAATG \\
\hline
\end{tabular}

\subsubsection{Screening of Antibiotic Types and Concentrations}

A. phaeospermum was inoculated on PDA medium containing $100 \mu \mathrm{g} / \mathrm{mL}$ ampicillin, kanamycin, hygromycin and geneticin and cultured in a $25{ }^{\circ} \mathrm{C}$ incubator for $5-7$ days. The growth status of $A$. phaeospermum was observed, and the antibiotics with the worst growth status were selected as selection markers. Concentrations of $0,50,100,150,200,250,300$ and $350 \mu \mathrm{g} / \mathrm{mL}$ were set to select the optimal concentration of selected antibiotics.

\subsubsection{Construction of Knockout Vector}

We used an improved split-marker method to identify gene function [49]. Taking the CDS region of cutinase transcription factor 1 beta 1 (Ctf1 $\beta 1)$ and cutinase transcription Factor 1 beta 2 (Ctf1 $\beta 2$ ) gene as the center, $1300 \mathrm{bp}$ upstream and $1300 \mathrm{bp}$ downstream were selected as homologous arms to design primers to amplify homologous arms of $C t f 1 \beta$ from A. phaeospermum DNA. Meanwhile, primers were designed to amplify the hygromycin phosphotransferase gene (hph) from the pSilent-1 vector. (The primer sequence is shown in Table 3.) Amplification system: DNA $1 \mu \mathrm{L}, \mathrm{Ctf1} \beta-5-\mathrm{F} / \mathrm{R}(\mathrm{Ctf1} 1 \beta-3-\mathrm{F} / \mathrm{R}$ and hph-F/hph-R) $1 / 1 \mu \mathrm{L}, 2 \times$ TransTaq HiFi PCR SuperMix $25 \mu \mathrm{L}$, nuclease-free water $22 \mu \mathrm{L}$. Reaction procedure: $94{ }^{\circ} \mathrm{C} 5 \mathrm{~min}\left(94{ }^{\circ} \mathrm{C} 30 \mathrm{~s}, 55^{\circ} \mathrm{C} 30 \mathrm{~s}, 72{ }^{\circ} \mathrm{C} 2 \mathrm{~min}\right) 34$ cycles, $72{ }^{\circ} \mathrm{C} 10 \mathrm{~min}$. Ctf $1 \beta-5$, $C t f 1 \beta-3$ and hph gene fragments were obtained. The fusion fragments were obtained by fusion PCR using LA Taq (Takara). The first round PCR amplification system: Ctf1 $\beta-5$ $3 \mu \mathrm{L}, \mathrm{Ctf1} \beta-33 \mu \mathrm{L}$, hph $6 \mu \mathrm{L}, 10 \times$ LA buffer $3 \mu \mathrm{L}$, dNTP Mix $1 \mu \mathrm{L}$, LA Taq $0.3 \mu \mathrm{L}$, $\mathrm{ddH}_{2} \mathrm{O}$ $13.7 \mu \mathrm{L}$. Reaction procedure: $94{ }^{\circ} \mathrm{C}$ for $3 \mathrm{~min},\left(94{ }^{\circ} \mathrm{C}\right.$ for $30 \mathrm{~s}, 55^{\circ} \mathrm{C}$ for $1 \mathrm{~min}, 72{ }^{\circ} \mathrm{C}$ for $2 \mathrm{~min}$ ), 34 cycles, $72^{\circ} \mathrm{C}$ for $7 \mathrm{~min}$. Second round PCR amplification system: The first round PCR product $2 \mu \mathrm{L}, 10 \times$ LA buffer $5 \mu \mathrm{L}$, dNTP mix $2 \mu \mathrm{L}$, LA Taq $0.5 \mu \mathrm{L}, \mathrm{ddH}_{2} \mathrm{O} 37.5 \mu \mathrm{L}$, Ctf $1 \beta-5-\mathrm{F} / \mathrm{Ctf1} \beta-3-\mathrm{R} 1 / 1 \mu \mathrm{L}$. Reaction procedure: $94{ }^{\circ} \mathrm{C} 3 \min \left(94{ }^{\circ} \mathrm{C} 30 \mathrm{~s}, 60{ }^{\circ} \mathrm{C} 30 \mathrm{~s}, 72{ }^{\circ} \mathrm{C}\right.$ $3 \mathrm{~min}) 34$ cycles, $72{ }^{\circ} \mathrm{C} 10 \mathrm{~min}$. The fusion fragment $C t f 1 \beta-5-\mathrm{hph}-\mathrm{Ctf} 1 \beta-3$ was obtained. Enzyme digestion system: $10 \times$ QuickCut Green Buffer $5 \mu \mathrm{L}$, pCAMBIA0380 DNA $7 \mu \mathrm{L}$, ApaI $1 \mu \mathrm{L}$, Hind III $1 \mu \mathrm{L}$, ddH $\mathrm{H}_{2} \mathrm{O} 36 \mu \mathrm{L}$. Procedure reaction: $37^{\circ} \mathrm{C}$ for $5 \mathrm{~min}$. We obtained vector pCAMBIA0380 linearized by ApaI and HindIII the fusion fragment containing the complementary sequences at ApaIand HindIII of vector pCAMBIA0380. The vector pCAMBIA0380 and fusion fragment $C t f 1 \beta-5-h p h-C t f 1 \beta-3$ were ligated by clonExpress II one step cloning kit (Vazyme Biotech Co., Ltd., Nanjing, China). Linked reaction system: linearized pCAMBIA0380 $5 \mu \mathrm{L}$. Fusion fragment $3 \mu \mathrm{L}, 5 \times$ CEIIBuffer $4 \mu \mathrm{L}$, Exnase $2 \mu \mathrm{L}$ and $\mathrm{ddH}_{2} \mathrm{O} 6 \mu \mathrm{L}$. Procedure reaction: $37^{\circ} \mathrm{C}$ for $30 \mathrm{~min}$, and cooling at $4{ }^{\circ} \mathrm{C}$ for $5 \mathrm{~min}$. The recombinant plasmid was transformed with DH5 $\alpha$ (TransGen Biotech, Beijing, China), the plasmid was added to $50 \mu \mathrm{L} \mathrm{DH} 5 \alpha$, then ice bathed $25 \mathrm{~min}, 42{ }^{\circ} \mathrm{C} 30 \mathrm{~s}$, ice bathed $2 \mathrm{~min}$, 
$500 \mathrm{uL}$ SOC liquid medium was been added in it, and shaken $200 \mathrm{rmp}$ at $37^{\circ} \mathrm{C}$ for $1 \mathrm{~h}$. and detected by colony PCR.

Table 3. $C t f 1 \beta 1$ and $C t f 1 \beta 2$ Gene knockout and complement experiment primer.

\begin{tabular}{|c|c|}
\hline Primer Name & Primer Sequence $5^{\prime}-3^{\prime}$ \\
\hline Ctf1ß1-5-F & TAGGCCACCATGTTGGGCCCGCTGGCGTGTTGAGCATGA \\
\hline Ctf1 $\beta 1-5-\mathrm{R}$ & AGTTCAGGCTTTTTCATATCTGGCAGGGCTGTTGGTAGA \\
\hline Ctf1ß1-3-F & CGAGGGCAAAGGAATAGAGTATGAAGCACGACCACCAGAT \\
\hline Ctf1 1 1-3-R & GTGGACTCCTCTTAAAGCTTCGGCGAAAGTGAGTGGATT \\
\hline Ctf1 $\beta 2-5-\mathrm{F}$ & TTCGGGTTACTTCCCTTCG \\
\hline Ctf1 $\beta 2-5-\mathrm{R}$ & AGTTCAGGCTTTTTCATATCAGGACGCATTAGTCGAGGC \\
\hline Ctf1 $\beta 2-3-\mathrm{F}$ & CGAGGGCAAAGGAATAGAGTTTAGGGCGTCATCTCGGTC \\
\hline Ctf1 $\beta 2-3-R$ & CCAGCATTCGTCAATATCAAGC \\
\hline Hph-F & GATATGAAAAAGCCTGAACT \\
\hline$H p h-\mathrm{R}$ & АСТСТАТTССТTTGСССТCG \\
\hline Ctf1 $\beta 1-\mathrm{F}$ & ATGGCCCCAAAAGACGGACTTTTGTCAG \\
\hline Ctf1 $\beta 1-\mathrm{R}$ & GCGTACGAAGCTTCAGCTG TCAATGTGTGTGGCCAAGGCAAAGCT \\
\hline Ctf1 $\beta 2-\mathrm{F}$ & ATGGCCGCAGACAACGAAGCTGT \\
\hline Ctf1 $\beta 2-\mathrm{R}$ & GCGTACGAAGCTTCAGCTG TTACСССТTTACCATACССССGTCC \\
\hline KanMX-F & $\overline{\text { CAGCTGAAGCTTCGTACGC }}$ \\
\hline KanMX-R & GCATAGGCCACTAGTGGATCTG \\
\hline Ctf1ß1-Up-F & GCTGGCGTGTTGAGCATGA \\
\hline Ctf1ß1-Up-R & CTGACAAAAGTCCGTCTTTTGGGGCCATTGGCAGGGCTGTTGGTAGA \\
\hline Ctf1ß1-Down-F & CAGATCCACTAGTGGCCTATGCATGAAGCACGACCACCAGAT \\
\hline Ctf1 $\beta 1-D o w n-R$ & CGGCGAAAGTGAGTGGATT \\
\hline Ctf1 $\beta 2-U p-F$ & TTCGGGTTACTTCCCTTCG \\
\hline Ctf1 $1 \beta 2-U p-R$ & ACAGCTTCGTTGTCTGCGGCCATAGGACGCATTAGTCGAGGC \\
\hline Ctf1ß2-Down-F & CAGATCCACTAGTGGCCTATGC TTAGGGCGTCATCTCGGTC \\
\hline Ctf1ß2-Down-R & $\overline{\text { CCAGCATTCGTCAATATCAAGC }}$ \\
\hline
\end{tabular}

Note: The sequence at the underline of the primer can be complementary paired with the sequences at both ends of the HPH fragment, and the red sequence can be complementary paired with the sequences at the vector enzyme digestion sites ApaI and Hind III.

\subsubsection{PEG-Mediated Protoplast Transformation}

Protoplast preparation: Preparation of enzymatic hydrolysate: $0.2 \mathrm{~g}$ lysine, $0.5 \mathrm{~g}$ driselease, $20 \mathrm{~mL} 1.2 \mathrm{M} \mathrm{KCl}$, magnetic stirring beads, stirring for $15 \mathrm{~min}$, then $4{ }^{\circ} \mathrm{C}$, $3500 \mathrm{rmp}$, acceleration of both up and down, centrifugation for $10 \mathrm{~min}$. The supernatant was filtered through a bacterial filter to obtain the enzymatic hydrolysate. The mycelia were cultured for 2 days at $28^{\circ} \mathrm{C}$, and $180 \mathrm{rpm}$ were filtered with single layer microcloth, washed with $25 \mathrm{~mL} 1.2 \mathrm{M} \mathrm{KCl}$, added to the enzymatic hydrolysate, and cultured at $70 \mathrm{rpm}$ and $30{ }^{\circ} \mathrm{C}$ for $9 \mathrm{~h}$. The protoplasts were examined by microscopy, filtered by double-layer microscopy, washed with $25 \mathrm{~mL}$ of $1.2 \mathrm{M} \mathrm{KCl}$, and centrifuged, and the supernatant was discarded. Then, $1 \mathrm{~mL}$ STC was added to the suspension for standby.

Genetic transformation: Then, $30 \mu \mathrm{L}$ of the fusion fragment Ctf1 $\beta$-5-hph-Ctf1 $\beta$-3 was added to the $5 \times 10^{6}$ protoplast and incubated at room temperature for $20 \mathrm{~min}$. PEG was added three times, with an interval of $10 \mathrm{~min}$ each time and $400 \mu \mathrm{L}$ was added each time. After standing at room temperature for $20 \mathrm{~min}, 10 \mathrm{~mL}$ TB3 liquid medium was added. The components of TB3 medium included yeast extract $3 \mathrm{~g}$, acid hydrolyzed casein $3 \mathrm{~g}$, sucrose $200 \mathrm{~g}$ and distilled water $1 \mathrm{~L}$. Then, after culturing at $90 \mathrm{RMP}$ and $25^{\circ} \mathrm{C}$ for $10 \mathrm{~h}, 45 \mathrm{~mL}$ TB3 medium containing $350 \mu \mathrm{g} / \mathrm{mL}$ hyg antibiotic was added to the protoplast. The plate was poured after mixing, the culture was inverted at $25^{\circ} \mathrm{C}$ for 3 days.

Transformant detection: Lysis buffer for microorganization to direct PCR (TaKaRa) was used to lyse the mycelium, and Ex Taq was used for detection. Hph-F/hph-R, (Ctf1 $\beta-3-h p h)-$ $\mathrm{F} / \mathrm{R},(\mathrm{Ctf1} \beta-5-\mathrm{hph})-\mathrm{F} / \mathrm{R}$ and $\mathrm{Ctf1} \beta-\mathrm{F} / \mathrm{Ctf1} \beta-\mathrm{R}$ were used for internal detection.

\subsubsection{Phenotype Analysis of Transformant}

To analyze the differences in vegetative growth among the strains, the morphology was observed, and the diameter of colonies was measured at 5 days after inoculation on PDA plates. Stress sensitivity assays were conducted on PDA plates supplemented with different agents: $2 \mathrm{mg} / \mathrm{mL}$ Congo red (CR), $2 \mathrm{~mol} / \mathrm{L} \mathrm{NaCl}$, and $40 \mathrm{mmol} / \mathrm{L} \mathrm{H}_{2} \mathrm{O}_{2}$ at $25^{\circ} \mathrm{C}$ 
for 5 days. All assays were repeated three times, and all data were analyzed by one-way ANOVA and Duncan's range test in SPSS 16.0 to measure specific differences between pairs of means. A $p$ value of $<0.05$ was considered statistically significant.

\subsubsection{Pathogenicity Test}

Twenty plants of two-year-old B. pervariabilis $\times D$. grandis with uniform growth were selected. Five plants were randomly selected and sprayed on the upper eight shoots of each plant with the mycelial suspension of the wild-type strain. The remaining 15 plants were treated with the mycelial suspension of mutant $\triangle \mathrm{APCtf1} \beta 1$, the mycelial suspension of mutant $\triangle \mathrm{APCtf1} \beta 2$ and sterile water, with five plants per treatment. The samples were subjected to bagging moisturizing and sprayed once every $12 \mathrm{~h}, 3$ times in total, using 3 independent replicates. The incidence was investigated 20 days after inoculation. The disease index was calculated as follows [50]. Disease grading standard: Grade 0: no wilt; Grade 1: less than 25\% branches withered; Grade 2: $25-50 \%$ (including 25\% and 50\%) branches withered; Grade 3: 50-75\% of the branches are dead (including 75\%); Grade 4: more than $75 \%$ branches withered.

$$
\begin{aligned}
& \text { Disease index }=[\Sigma \text { (Disease grade } \times \text { Number of diseased } \\
& \text { branches }) /(\text { total branches }) \times \text { The most serious disease grade }] \times 100 \text {. }
\end{aligned}
$$

\subsubsection{Complementation Test of Ctf1 $\beta$ Knockout}

Taking the CDS region of hph gene as the center, $1300 \mathrm{bp}$ upstream and $1300 \mathrm{bp}$ down-stream were selected as homologous arms to design primers (the complementary sequence of the upstream primer of KanMx gene was added at the 5 'end of the downstream primer of the upstream homologous arm, the complementary sequence of the downstream primer of KanMx gene was added at the 5 'end of the upstream primer of the downstream homologous arm as shown in Table 3) to amplify homologous arms. The KanMx gene was amplified from PUG6 plasmid DNA as a screening marker gene, and kanMx-Ctf1 $\beta 1$ and kanMx-Ctf1 $\beta 2$ recombinant fragments were obtained by two rounds of fusion PCR. The gene knockout complement vectors KanMx-Ctf1 $\beta$ 1-5/KanMx-Ctf1 $\beta$ 1-3 and KanMxCtf1 $\beta$ 2-5/KanMx-Ctf1 $\beta$ 2-3 were constructed by using the improved spike marker method with reference to the method (Figure S1). The amplification system and reaction procedures of the first and second rounds of PCR were consistent with those in Section 2.2.8. Then, $30 \mu \mathrm{L}$ each for KanMx-Ctf1 $\beta 1-5 / \mathrm{KanMx}+\mathrm{Ctf1} \beta$ 1-3 and KanMx-Ctf1 $\beta$ 2-55/KanMxCtf1 $\beta$ 2-3 were added to the protoplast, and the fragments were transferred into the $5 \times 10^{6}$ protoplasts according to the method in Section 2.2.9. The primers KanMx-Ctf1 $\beta$ 1-F/KanMx-Ctf1 $\beta$ 1-R and KanMx-Ctf1 $\beta 2-\mathrm{F} / \mathrm{KanMx}+\mathrm{Ctf1} \beta 2-\mathrm{R}$ were used for internal inspection. KanMx-Ctf1 $\beta$ 1-5-F/R and KanMx-Ctf1 $\beta$ 2-5-F/R were used for external inspection. Stress sensitivity assays were conducted on PDA plates supplemented with different agents: $2 \mathrm{mg} / \mathrm{mL}$ Congo red (CR), $2 \mathrm{~mol} / \mathrm{L} \mathrm{NaCl}$, and $40 \mathrm{mmol} / \mathrm{L} \mathrm{H}_{2} \mathrm{O}_{2}$ at $25^{\circ} \mathrm{C}$ for 5 days to analyze the differences in vegetative growth among the strains. For the pathogenicity determination, twenty plants of two-year-old B. pervariabilis $\times D$. grandis with uniform growth were selected. Five plants were randomly selected and sprayed on the upper eight shoots of each plant with the mycelial suspension of the wild-type strain. The remaining 15 plants were treated with the mycelial suspension of $C t f 1 \beta 1$ complemented strain and Ctf $1 \beta 2$ complemented strain, and sterile water, with five plants per treatment. The samples were subjected to bagging moisturizing and sprayed once every $12 \mathrm{~h}, 3$ times in total, using 3 independent replicates. The incidence was investigated 20 days after inoculation. Refer to Section 2.2.11 for the calculation of disease index. 


\section{Results}

\subsection{Transcriptome Sequencing Results}

\subsubsection{Growth of Fungi in Different Plant Tissue Culture Condition}

The results showed that $A$. phaeospermum grew faster and better in sterile B. pervariabilis $\times D$. grandis tissue liquid culture than in sterile deionized water and sterile rice tissue liquid culture. The growth curve of $A$. phaeospermum under three different culture conditions is shown in Figure 1. The results showed that the colony diameter cultured in the PDA medium containing B. pervariabilis $\times D$. grandis tissue was $82.6 \mathrm{~mm}$, which is significantly bigger than those of cultured in the medium containing rice tissue and sterile deionized water PDA medium.

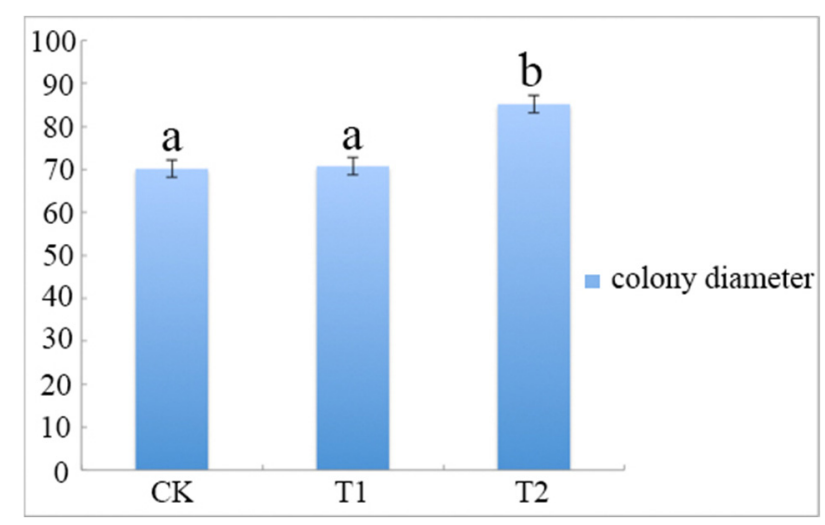

Figure 1. The colony diameter of A. phaeospermum after 7 days of culture under CK, T1 and T2. Note: All assays were repeated three times; the data were analyzed using one-way ANOVA and Duncan's range test in SPSS 16.0. Different lowercase letters showed that there were significant differences in colony diameter under different treatment conditions $(p \leq 0.01)$.

\subsubsection{RNA Quality Detection}

The quality of RNA was tested by agarose gel electrophoresis, NanoDrop spectrophotometry and Agilent 2100. The agarose gel electrophoresis results showed that the 28S:18S rRNA ratio of all the samples was 2:1, and RNA integrity was sound. In addition, the concentration of RNA in 9 samples was more than $500 \mathrm{ng} / \mu \mathrm{L}$. In the total RNA purity test, the A260/A280 ratio of all samples was between 1.9 and 2.0. That is, the 9 RNA samples extracted had no DNA, impurity contamination or degradation and could meet the requirement of constructing libraries.

\subsubsection{Sequencing Data and DEG Statistics}

The base percentage of Q30 in each sample after filtering was not less than $94.76 \%$. The percentage of GC content was more than $56.46 \%$. The reads' lengths of 9 samples are $150 \mathrm{bp}$. The transcriptome sequencing results met the quality requirements of subsequent assembly analysis. The sequencing information of samples CK-1, CK-2, CK-3, T1-1, T1-2, T1-3, T2-1, T2-2 and T2-3 is shown in Table 4. We used short read alignment software Bowtie2 to align high-quality clean reads with reference contig sequences, which was obtained by transcriptome de novo assembly. Statistical results of comparisons between samples and reference contigs are shown in Table 5. In addition, we aligned the assembled A. phaeospermum transcriptome sequences with the A. phaeospermum genome. The alignment rates of 9 samples (CK-1, CK-2, CK-3, T1-1, T1-2, T1-3, T2-1, T2-2 and T2-3) were $85.00 \%$, $86.08 \%, 85.11 \%, 84.81 \%, 84.17 \%, 79.07 \%, 83.10 \%, 81.61 \%$ and $83.97 \%$, respectively (Table S1). By Illumina sequencing and Trinity reassembly, the average continuous length was $2302 \mathrm{bp}$, and the N50 was $3326 \mathrm{bp}$. We assembled 30,620 contigs through Trinity and finally obtained 13,077 merged contigs through TGICL clustering and removing redundancy. Therefore, a total of 13,077 merged contigs were obtained from 9 samples. There were 12,845, 12,697 and 13,055 contigs in sterile deionized water and sterile B. pervariabilis $\times D$. grandis tissue 
fluid, which accounted for $98.23 \%, 97.09 \%$ and $99.83 \%$ of the total contigs, respectively. Busco (version: 3.0.3, lineage dataset: Ascomycota_odb9) analysis results of sequence assembly quality are shown in Figure S2. Complete busco (including complete and singlecopy BUSCOs and complete and duplicated BUSCOs) accounts for $92 \%$ of the total. All transcriptomic data of 9 samples of $A$. phaeospermum were deposited in the NCBI Sequence Reads Archive (SRA) under the accession numbers SRR9278662, SRR9278661, SRR9278664, SRR9278663, SRR9278658, SRR9278657, SRR9278660, SRR9278659 and SRR9278665. The assembled contigs have been published in the NCBI Transcriptome Shotgun Assembly (TSA) under the accession number GHWG00000000 (https://www.ncbi.nlm.nih.gov/ nuccore/GHWG00000000.1/, accessed on 1 October 2019), including 12,861 contigs that came from the filters applied by TSA.

Table 4. Sequencing data statistics of the nine samples.

\begin{tabular}{ccccc}
\hline Sample & Clean Reads & GC Content & Reads Lenth & $\mathbf{\%} \geq \mathbf{Q 3 0}$ \\
\hline CK-1 & $52,922,016$ & $56.50 \%$ & 150 & $94.95 \%$ \\
CK-2 & $50,075,888$ & $56.65 \%$ & 150 & $94.92 \%$ \\
CK-3 & $48,964,936$ & $56.68 \%$ & 150 & $94.76 \%$ \\
T1-1 & $50,112,716$ & $56.56 \%$ & 150 & $94.87 \%$ \\
T1-2 & $58,737,286$ & $56.47 \%$ & 150 & $94.95 \%$ \\
T1-3 & $48,459,904$ & $56.39 \%$ & 150 & $94.92 \%$ \\
T2-1 & $50,093,080$ & $56.47 \%$ & 150 & $94.96 \%$ \\
T2-2 & $66,878,600$ & $56.52 \%$ & 150 & $94.76 \%$ \\
T2-3 & $59,806,800$ & $56.46 \%$ & 150 & $94.78 \%$ \\
\hline
\end{tabular}

Cultured in sterile deionized water medium for 7 days (CK); Cultured in sterile rice tissue liquid medium for 7 days (T1); Cultured in sterile B. pervaiabilis $\times$ D. grandis tissue fluid medium for 7 days (T2). Each treatment group had three duplications.

Table 5. Statistical results of 9 samples compared with reference genes.

\begin{tabular}{ccccc}
\hline Sample & All Reads Number & $\begin{array}{c}\text { Unique Mapped } \\
\text { Reads }\end{array}$ & $\begin{array}{c}\text { Multiple Mapped } \\
\text { Reads }\end{array}$ & $\begin{array}{c}\text { Mapping } \\
\text { Ratio }\end{array}$ \\
\hline CK-1 & $49,948,918$ & $42,069,088$ & $3,839,542$ & $91.91 \%$ \\
CK-2 & $48,644,554$ & $38,417,922$ & $3,768,346$ & $86.72 \%$ \\
CK-3 & $46,816,432$ & $39,365,841$ & $3,686,520$ & $91.96 \%$ \\
T1-1 & $48,309,274$ & $40,649,369$ & $4,017,201$ & $92.46 \%$ \\
T1-2 & $55,871,212$ & $46,619,707$ & $5,052,812$ & $92.49 \%$ \\
T1-3 & $44,845,488$ & $37,341,346$ & $3,447,631$ & $90.95 \%$ \\
T2-1 & $47,835,204$ & $40,423,506$ & $3,689,078$ & $92.22 \%$ \\
T2-2 & $63,877,526$ & $54,410,080$ & $4,332,707$ & $91.96 \%$ \\
T2-3 & $57,266,814$ & $48,703,596$ & $4,118,072$ & $92.24 \%$ \\
\hline
\end{tabular}

The contig sequences of $A$. phaeospermum under the three different treatment conditions were annotated and compared with SwissProt databases, Kyoto Encyclopedia of Genes and Genomes (KEGG) the Clusters of Protein Homology (KOG) and NCBI nonredundant $(\mathrm{Nr})$ protein databases. The additional remonal redundant sequences obtained a total of 13,077 contigs. There were 10,155 contigs with annotated information in four major databases (Figure 2). Among these contigs, 3247 contigs were annotated in four databases at the same time. A total of 7271, 3714, 5904 and 9991 genes were annotated in the SwissPort, KEGG, KOG and NR databases, respectively. Based on the GO annotations, 3394 contigs were annotated into biological processes, including metabolic processes, cellular processes, single-organism processes and biological regulation. A total of 3111 contigs were annotated into cell components, in which contigs act mainly on cell parts, organelles, macromolecule complexes, cell membranes, etc. There were 2239 contigs annotated in molecular function. Most of them have catalytic activity, binding, transporter activity, structural molecular activity, molecular function regulator activity and other functions. The ten top species based on the $\mathrm{Nr}$ annotations are shown in Figure 3. 


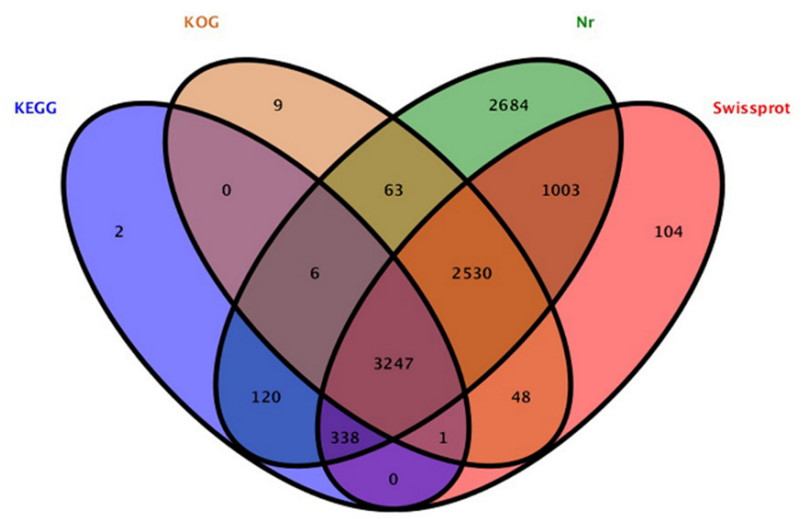

Figure 2. Annotation results of total genes in KEGG, KOG, Nr and Swissprot datasets.

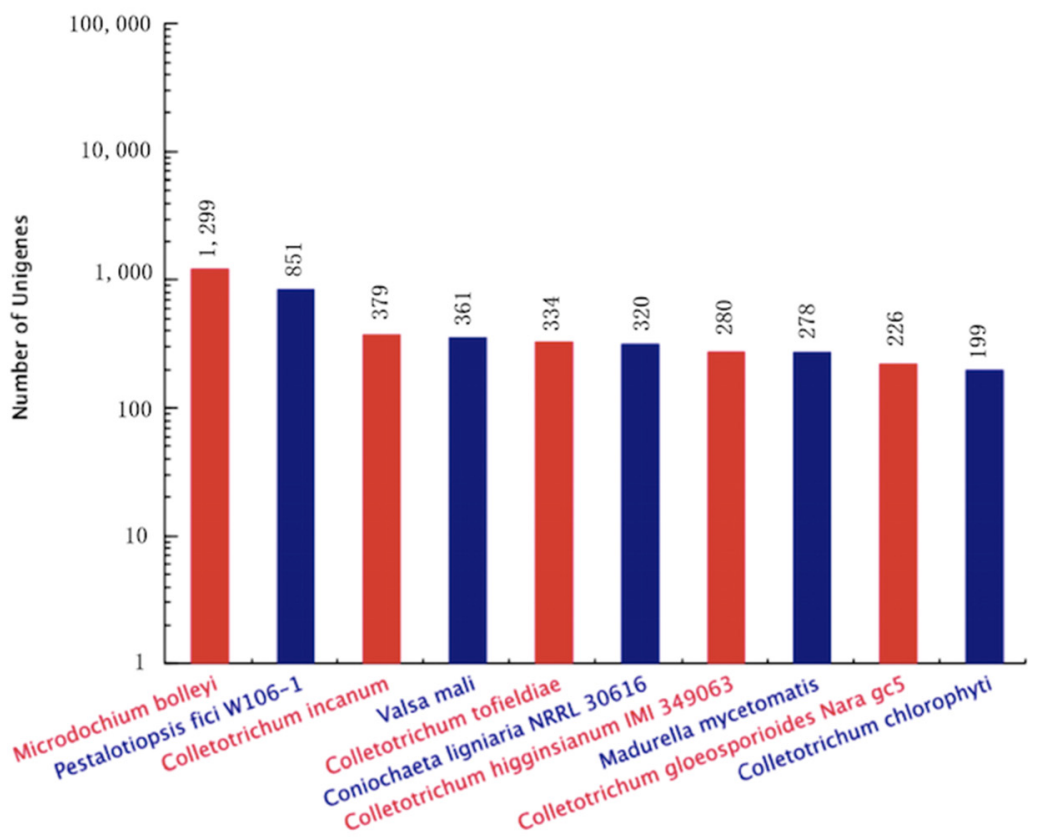

Figure 3. Statistical map of top ten species distribution.

When comparing the DEGs of three different culture conditions in pairs, 4 DEGs were found to be upregulated and 367 were downregulated in CK-vs-T1 (Supplementary Table S2), 263 genes were upregulated and 161 were downregulated in CK-vs-T2 (Supplementary Table S3), 323 genes were upregulated and 148 were downregulated in T1-vs-T2 (Supplementary Table S4). The numbers of DEGs were similar between the CK-vs-T2 and T1-vs.-T2 comparisons, the number of DEGs in both comparison groups was large, and both contained cutinase transcription Factor 1 beta. The results showed a significant difference between the culture of the pathogen in the host plant $B$. pervariabilis $\times D$. grandis. tissue medium and the culture of the pathogen in the nonhost plant sterile rice tissue medium or sterile deionized water. In contrast, the number of DEGs was the smallest in the CK-vs-T1 comparison, indicating a small difference between these two conditions. The differentially expressed genes between different groups under the three conditions are shown in a volcano plot (Figure 4). 


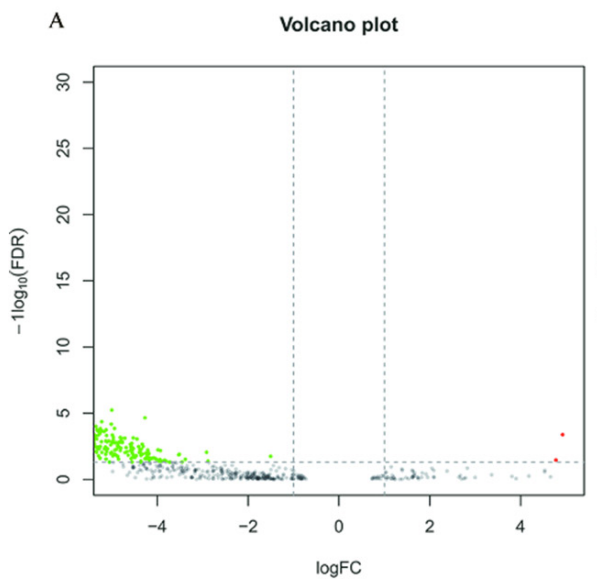

B

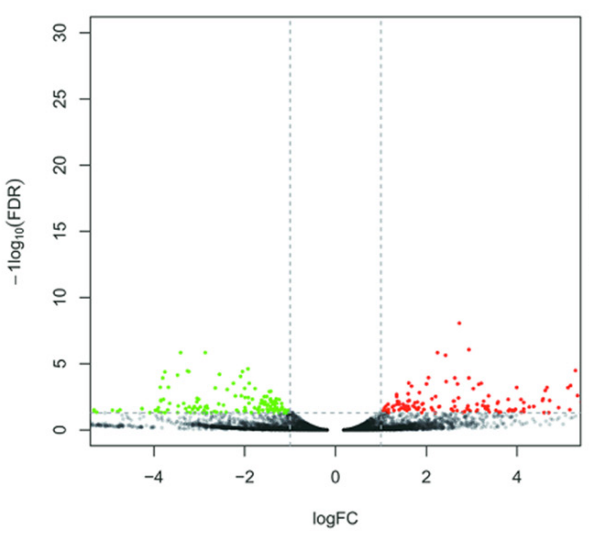

C

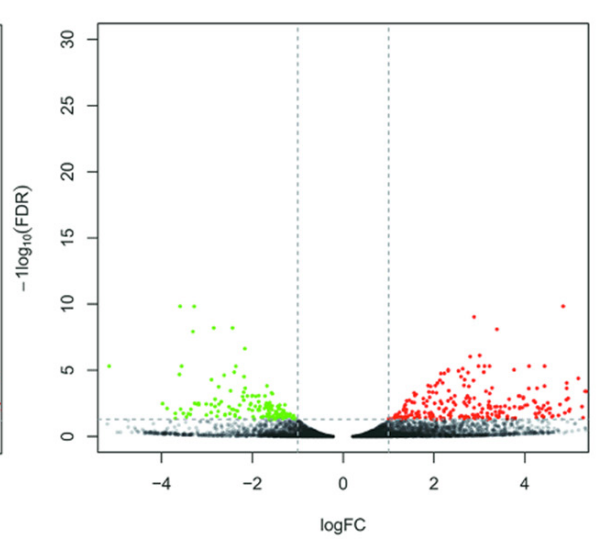

Figure 4. Differential Expressed Gene Volcano plot of CK vs. T1 (A), T1 vs. T2 (B) and CK vs. T2 (C) comparison groups. Note: Red represents genes that are upregulated, green represents genes that are downregulated, and black represents no difference. FDR $<0.05$ and a difference multiple greater than 2 were used as the criteria for judging the difference in expression levels.

\subsection{KEGG and GO Annotation Analysis of DEGs}

$\mathrm{GO}$ functional enrichment analysis was carried out for the differentially expressed genes of A. phaeospermum under three different treatment conditions. In the GO enrichment analysis of the CK and T1 treatment groups, there were no upregulated differentially expressed genes, while 91, 99 and 63 downregulated genes were annotated by biological processes, cell components and molecular functions, respectively (Figure 5A). In the GO enrichment analysis of the CK and T2 groups in the control group, 22, 10 and 33 upregulated genes and 36, 10 and 35 downregulated genes related to biological processes, cell components and molecular functions were obtained. The GO classification of the differentially expressed genes of A. phaeospermum in sterile deionized water and sterile B. pervariabilis $\times D$. grandis. tissue fluid culture is shown in Figure $5 B$. In the GO enrichment analysis of the T1 and T2 treatment groups, 36, 10 and 53 upregulated genes and 47, 21 and 50 downregulated genes were obtained, respectively. The distribution of up- and downregulated genes in the GO function was basically consistent with the distribution of up- and downregulated genes in the CK and T2 treatment groups. The GO classification of differentially expressed genes of A. phaeospermum in sterile rice tissue fluid and sterile $B$. pervariabilis $\times D$. grandis. tissue fluid culture is shown in Figure 5C. KEGG functional enrichment analysis was performed on the differentially expressed genes of $A$. phaeospermum treated with sterile deionized water, sterile rice tissue fluid and sterile hybrid B. pervariabilis $\times D$. grandis. fluid. In the KEGG enrichment analysis of the CK and T1 treatment groups in the control group (Figure 6A), there were 144 DEGs in the KEGG pathway. One of the upregulated DEGs controls the metabolic pathway of oxidative phosphorylation. There were 143 downregulated DEGs, which mainly control RNA degradation, species longevity regulation and RNA transport. In the KEGG enrichment analysis of the CK and T2 treatment groups, the KEGG enrichment maps of CK in the control group and T2 in the treatment group are shown in Figure 6B. There were 43 DEGs and 25 upregulated DEGs. In the KEGG enrichment analysis of the T1 and T2 treatment groups, the KEGG enrichment maps of treatments $\mathrm{T} 1$ and $\mathrm{T} 2$ are shown in Figure $6 \mathrm{C}$. The main enrichment processes were upregulation and downregulation DEGs, including 51 DEGs and 26 upregulation DEGs. 

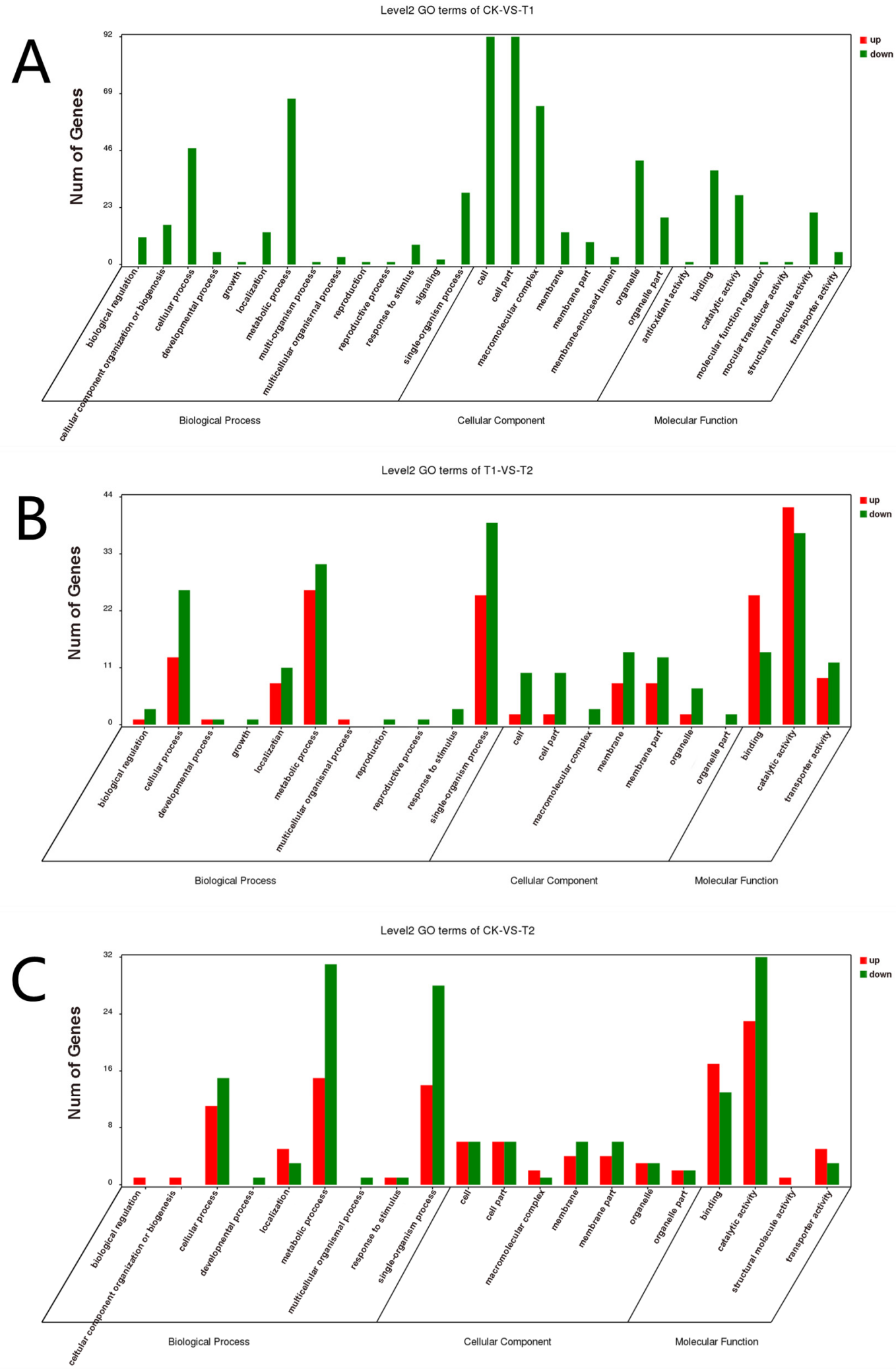

Figure 5. GO classification map of differentially expressed genes under different treatment conditions. (A) CK vs. T1; (B) CK vs. T2; (C) T1 vs. T2. Note: Red represents the up-regulated differentially expressed genes in the GO classification map, and green represents the down-regulated differentially expressed genes in the GO classification map. 

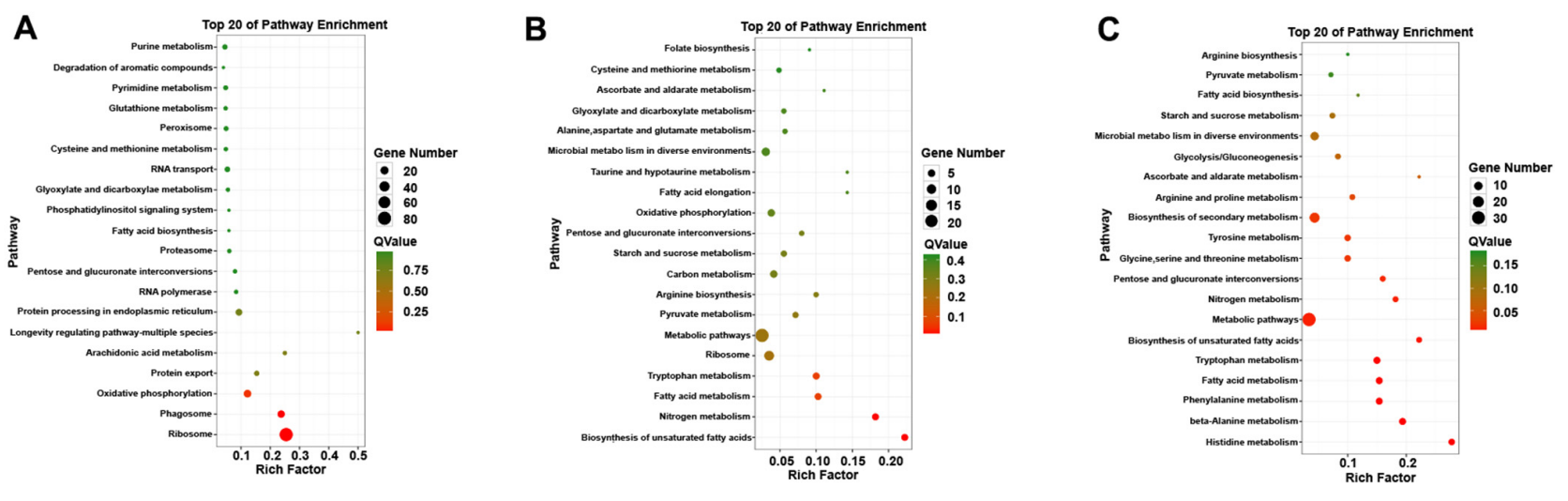

Figure 6. Summary of the KEGG enrichment map of different genes under different treatment conditions. (A) CK vs. T1; (B) CK vs. T2; (C) T1 vs. T2. Note: The size of the circle represents the number of differentially expressed genes KEGG enrichment map. The larger the circle, the more differentially expressed genes enriched in this pathway.

\subsection{Verification by $q R T-P C R$}

To verify the reliability of the RNA sequencing data, qRT-PCR was used to evaluate the expression under different culture conditions. When housekeeping genes GAPDH and Actin were used as internal reference genes, the expression trend of differential genes was the same and consistent with the results of transcriptome sequencing. We selected 10 DEGs from three different comparison groups to verify the change in expression (Figure 7). Among the 10 differentially expressed genes selected from the T1 and T2 treatment groups, 9 genes showed the same change trend as the result of transcriptome sequencing; only the change trend of $h y d p$ (hydrolase, partial) was inconsistent with the result of transcriptome sequencing, and the consistency rate was $90 \%$. Among the 10 differentially expressed genes selected from the CK and T2 treatment groups, 10 genes showed the same change trend as transcriptome sequencing, with a consistent rate of $100 \%$. Among the 10 differentially expressed genes selected from the CK and T1 treatment groups, all genes showed the same change trend as the result of transcriptome sequencing, with a consistent rate of $100 \%$. Among these genes, the expression of $C t f 1 \beta$ in the T2 group was significantly higher than the expression of $C t f 1 \beta$ in the CK group, which may be related to $A$. phaeospermum infection of $B$. pervariabilis $\times D$. grandis. needing to produce a large amount of cutinase to degrade cutin. In this case, $C t f 1 \beta$ is considered a gene related to $A$. phaeospermum virulence, it has further functional research value.

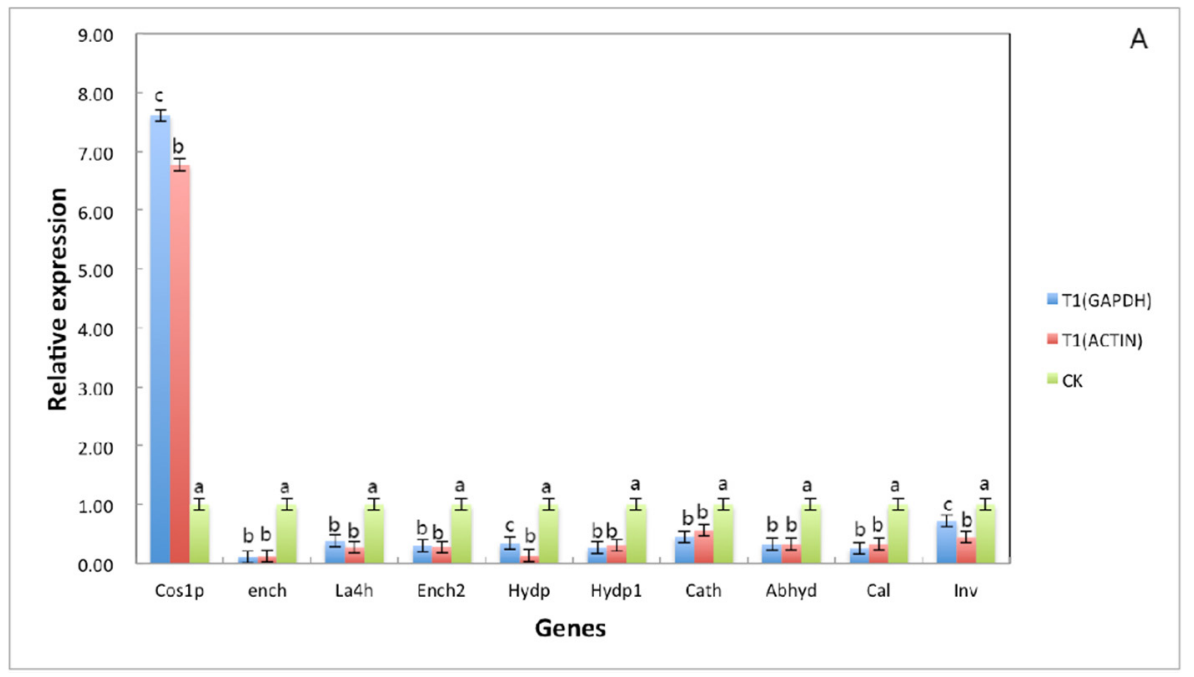

Figure 7. Cont. 


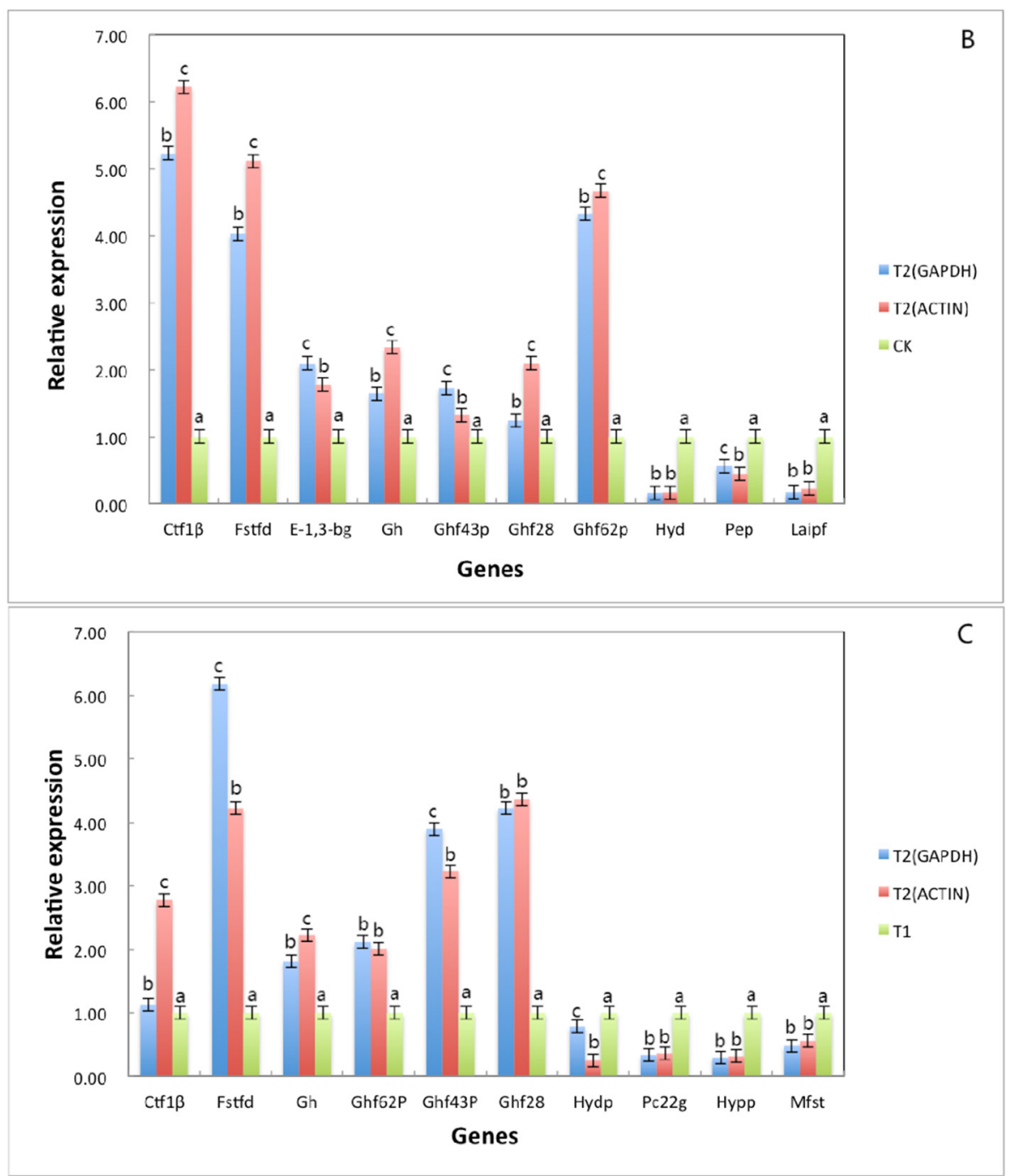

Figure 7. The differential gene expression under different treatment conditions was verified by fluorescence quantitative analysis. Note: (A) refers to the detection results of 10 differential gene expressions under two different culture conditions of sterile deionized water and sterile rice tissue fluid; (B) refers the detection results of 10 differential gene expressions under two different culture conditions of sterile deionized water and sterile tissue fluid of B. pervariabilis $\times D$. grandis; $(\mathbf{C})$ refers the detection results of 10 differential gene expressions under two different culture conditions of sterile rice tissue fluid and sterile B. pervariabilis $\times D$. grandis. tissue fluid. All assays were repeated three times, the data were analyzed using one-way ANOVA and Duncan's range test in SPSS 16.0. Different lowercase letters showed that there were significant differences in the expression level of the same gene under different treatment conditions. Blue represents the relative expression after normalization with GAPDH as the reference gene. Red represents the relative expression after normalization with actin as the reference gene $(p \leq 0.01)$.

\subsection{Gene Function Verification Results}

\subsubsection{Construction of Knockout Vector and Genetic Transformation}

Through the screening of antibiotic types and concentrations, when the concentration of hygromycin was $300 \mu \mathrm{g} / \mathrm{mL}$ or the concentration of genomycin was $50 \mu \mathrm{g} / \mathrm{mL}$, the mycelium was found to almost not grow, and when the concentration of hygromycin reached $350 \mu \mathrm{g} / \mathrm{mL}$ or the concentration of genomycin was $100 \mu \mathrm{g} / \mathrm{mL}$, the mycelium did not grow at all. Therefore, hygromycin and genomycin were selected as screening markers at concentrations of $350 \mu \mathrm{g} / \mathrm{mL}$ and $100 \mu \mathrm{g} / \mathrm{mL}$, respectively. The kill curve for hygromycin and genomycin were in the Figures S3 and S4. The results showed that the growth of 
A. phaeospermum was inhibited by hygromycin. The higher the concentration of hygromycin, the stronger the inhibition. When the concentration of hygromycin was $350 \mu \mathrm{g} / \mathrm{mL}$, the A. phaeospermum did not grow at all. Similarly, the growth of A. phaeospermum was inhibited by genomycin. The higher the concentration of genomycin, the stronger the inhibition. When the concentration of genomycin was $100 \mu \mathrm{g} / \mathrm{mL}$, the A. phaeospermum did not grow at all. The hph, Ctf1 $\beta 1-5^{\prime}, C t f 1 \beta 1-3^{\prime}, C t f 1 \beta 2-5^{\prime}$ and $C t f 1 \beta 2-3^{\prime}$ fragments were obtained by PCR amplification. The knockout vectors of the Ctf1 $\beta 1$ and $C t f 1 \beta 2$ genes were constructed successfully by the improved split-marker method. From left to right were $15 \mathrm{~K}$ DNA marker (TransGen Biotech), recombinant plasmid DNA, empty plasmid DNA, recombinant plasmid double digested product and $C t f 1 \beta 1$ and $C t f 1 \beta 2$ knockout vector fusion fragments (Figure S5). The mycelium was hydrolyzed with $0.2 \mathrm{~g}$ lysine and $0.5 \mathrm{~g}$ drisealsel, and a large number of protoplasts were obtained, which were swollen and transparent at a dilution concentration of $10^{7} / \mathrm{mL}$ (Figure 8). After the fusion fragment was transferred into the protoplast and cultured in TB3 medium for 3 days, the colony diagram is as follows (Figure 9). A single colony was transferred to a PDA plate with a hygromycin concentration of $350 \mu \mathrm{g} / \mathrm{mL}$, and several transformants were obtained after 4 days of culture. Then, "hph", "Ctf1 1 1", "Ctf1 $\beta 2$ ", "uphph" and "downhph" fragments of wild-type, Ctf1 $\beta 1$ and Ctf1 $\beta 2$ deletion mutant strains were detected by PCR, as shown in Figures S6 and S7. The sequencing results were consistent with the $h p h$ gene sequence.

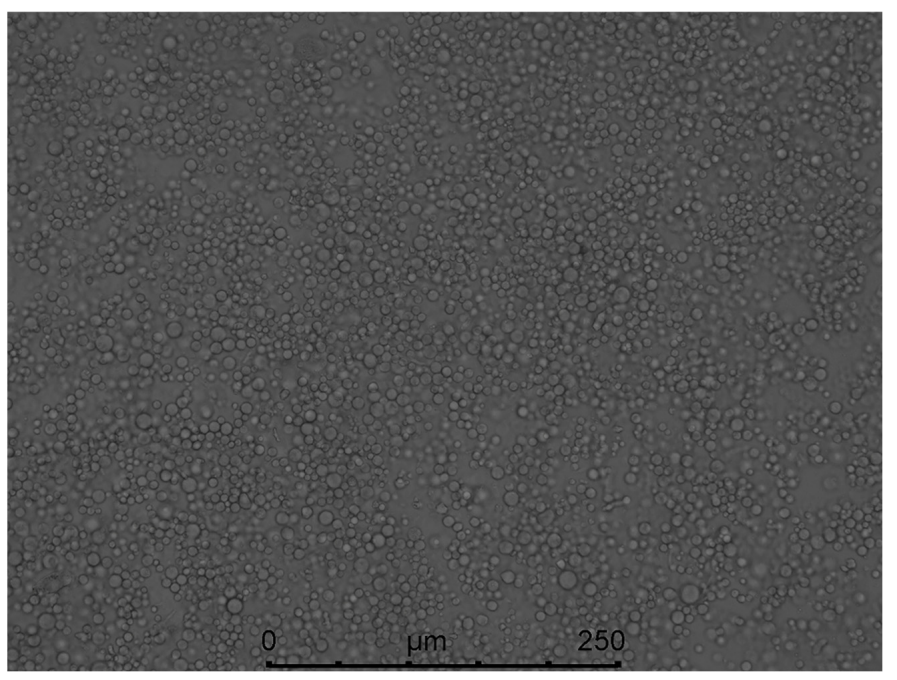

Figure 8. Morphology of A. phaeospermum protoplasts under $10 \times 40$ power optical microscope.

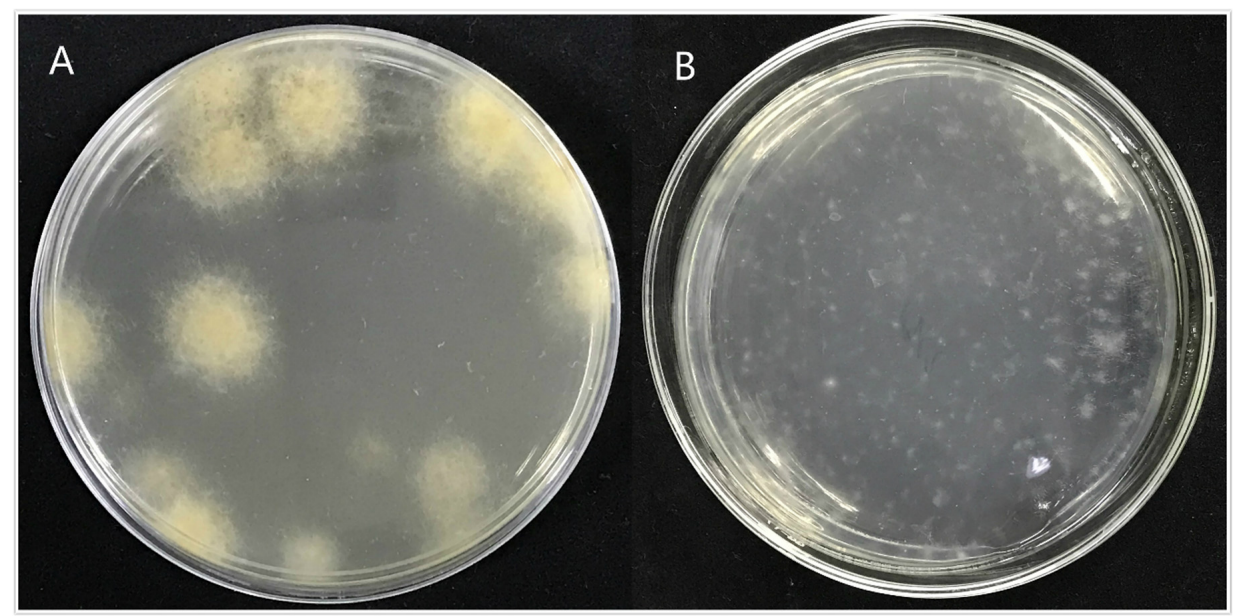

Figure 9. Colony diagram of transformant. Note: (A): Colony diagram of transformed strain $\triangle \mathrm{ApCtf1}$ $\beta$ after 4 days of incubation at 25. (B): Colony diagram of transformed strain $\triangle \mathrm{ApCtf1} \beta$ after one day of incubation at 25 . 


\subsubsection{Phenotypic Analysis of Transformant}

The phenotypes of the mutants were significantly different from the phenotypes of the wild type (Figure 10). Based on the percent growth inhibition of the strains relative to unstressed controls, both mutants were significantly more sensitive to the oxidative stress of $\mathrm{H}_{2} \mathrm{O}_{2}$ than the control strains. The relative growth inhibition of $\triangle \mathrm{ApCtf1} \beta 1$ and $\triangle \mathrm{ApCtf1} \beta 2$ colonies was significantly decreased by $21.4 \%$ and $19.2 \%$, respectively, by adding $40 \mathrm{mmol} / \mathrm{L} \mathrm{H}_{2} \mathrm{O}_{2}$ compared to the estimates from the wild-type strain. Moreover, two disruption mutants exhibited significantly decreased tolerance to Congo red. $\Delta \mathrm{Ap}$ Ctf1 $\beta 1$ and $\triangle$ Ap Ctf1 $\beta 2$ drastically decreased the colony growth areas by $25 \%$ and $19.4 \%$ at a concentration of $2 \mathrm{mg} / \mathrm{mL}$ Congo red, respectively. However, the hyperosmotic stress of $2 \mathrm{~mol} / \mathrm{L} \mathrm{NaCl}$ caused no significant differences in colony growth in either of the disruption mutants (Figures 11 and 12). These results indicate that $C t f 1 \beta 1$ and $C t f 1 \beta 2$ play an important role in oxidative stress response and cell wall inhibitor stress response of A. phaeospermum.

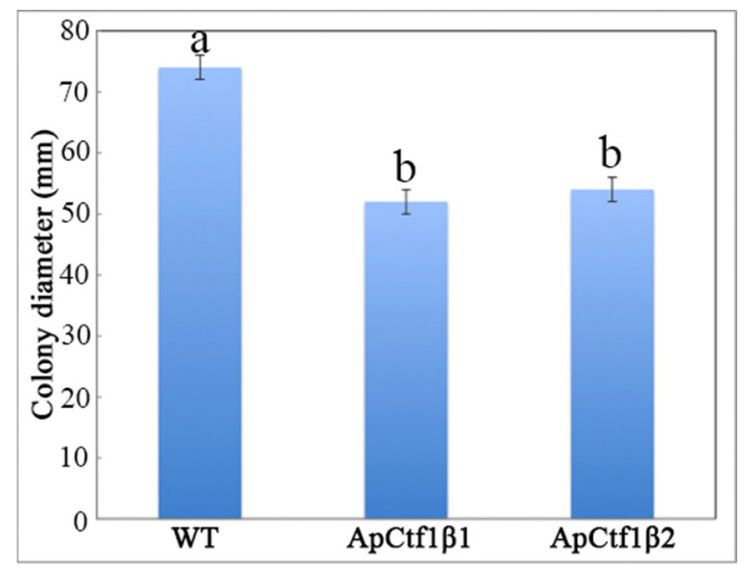

Figure 10. WT, ApCtf1 $\beta 1$ and ApCtf1 $\beta 2$ colony diameter after 7 days of culture at $25^{\circ} \mathrm{C}$. Note: $\mathrm{WT}, \mathrm{ApCtf1} \beta 1$ and ApCtf1 $\beta 2$ show the colony diameters of the wild-type, Ctf1 $\beta 1$ deletion mutant and Ctf1 $\beta 2$ deletion mutant of A. phaeospermum after culturing for 7 days, respectively. All assays were repeated three times, the data were analyzed using one-way ANOVA and Duncan's range test in SPSS 16.0. Different lowercase letters showed significant differences in colony diameter of strains $(p \leq 0.01)$.

\subsubsection{Pathogenicity Test of Transformant}

To determine whether $\triangle \mathrm{ApCtf1} \beta 1$ and $\triangle \mathrm{ApCtf1} \beta 2$ are involved in pathogenicity, we performed a pathogenicity test on twigs and leaves by inoculating mycelial plugs of the wild type, $\triangle$ ApCtf1 $\beta 1$ deletion mutant and $\triangle$ ApCtf1 $\beta 2$ deletion mutant. Mild symptoms were found on the $\triangle \operatorname{ApCtf1} \beta 1$ and $\triangle \operatorname{ApCtf1} \beta 2$ mutant-infected twigs after culture in a greenhouse (temperature: $20{ }^{\circ} \mathrm{C}$, humidity: $65 \%$ ), while obvious symptoms on twigs and leaves of B. pervariabilis $\times D$. grandis. were found in the wild-type strains (Figure 13). The statistical results of the disease index are shown in Figure 14. The disease index of $B$. pervariabilis $\times D$. grandis. inoculated with sterile water did not change with the increase of time, and they were all 0 . The disease index of $B$. pervariabilis $\times D$. grandis. inoculated with wild type, mutant $\triangle \mathrm{ApCtf1} \beta 1$ and mutant $\triangle \mathrm{ApCtf1} \beta 2$ were increased significantly with the increase of inoculation time. After 25 days of inoculation, the disease index reached $86.25 \%, 60 \%$ and $60 \%$ respectively. At the same time, we found that the disease index of $B$. pervariabilis $\times D$. grandis. inoculated with wild-type strain was significantly higher than that inoculated with mutant $\triangle \operatorname{ApCtf1} \beta 1$ strain and mutant $\triangle \operatorname{ApCtf1} \beta 2$ strain at the same time point. However, there was no significant difference in the disease index between mutant $\triangle \operatorname{ApCtf1} \beta 1$ and $\triangle \operatorname{ApCtf1} \beta 2$. (Figure 14). This result suggests that $C t f 1 \beta 1$ and $C t f 1 \beta 2$ play a key role in $A$. phaeospermum virulence. 


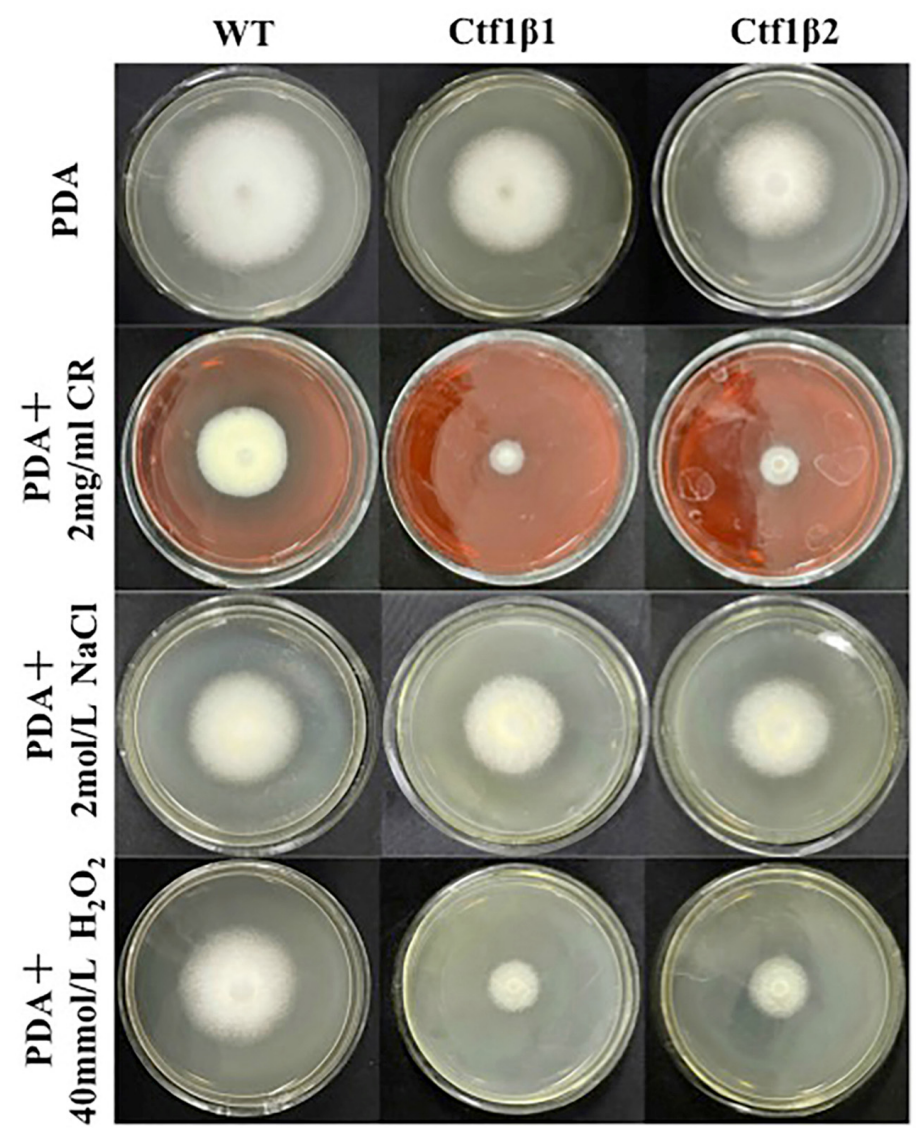

Figure 11. Comparison of the colony morphology and stress tolerance of wild-type, $\triangle \mathrm{ApCtf1 \beta 1}$ and $\triangle A p C t f 1 \beta 2$ strains. Note: The wild-type, $C t f 1 \beta 1$ deletion and $C t f 1 \beta 2$ deletion strains were inoculated on PDA media or PDA media appended with various stressors and cultured at $25^{\circ} \mathrm{C}$ in darkness for 5 days.

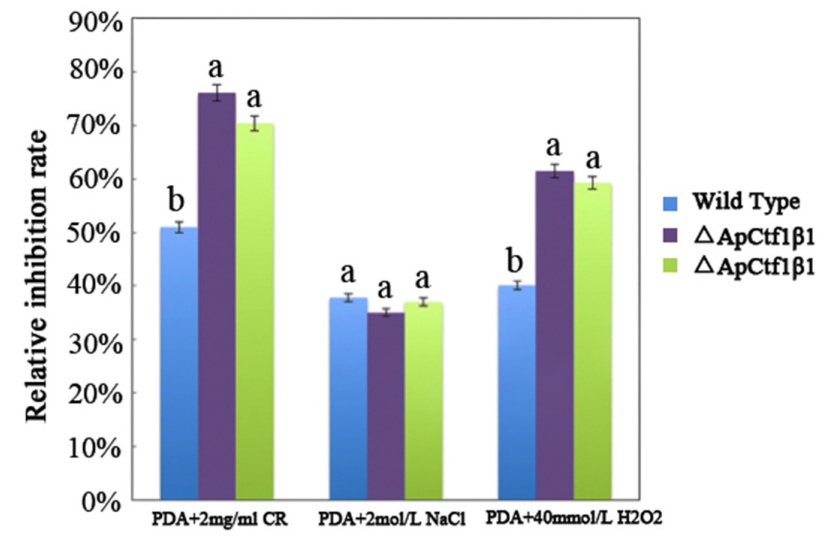

Figure 12. The bar chart showed the relative inhibition rate of wild type, $\triangle \mathrm{ApCtf1} \beta 1$ and $\triangle \mathrm{ApCtf1} \beta$ 2 strains after $\mathrm{CR}, \mathrm{NaCl}$ and $\mathrm{H}_{2} \mathrm{O}_{2}$ stress for 5 days, respectively. Note: The datasets were calculated from the image in Figure 11. The error bars represent the standard deviations based on three independent biological replicates with three technical replicates each. The relative inhibition rate of $\triangle \mathrm{ApCtf1 \beta} 1$ and $\triangle \mathrm{ApCtf1} \beta 2$ were significantly different from that of wild type after $C R$ and $\mathrm{H}_{2} \mathrm{O}_{2}$ stress. The relative inhibition rate of $\Delta \mathrm{ApCtf1} \beta 1$ and $\Delta \mathrm{ApCtf1} \beta 2$ were consistent with that of wild type after $\mathrm{NaCl}$ stress. All assays were repeated three times, the data were analyzed using one-way ANOVA and Duncan's range test in SPSS 16.0. Different lowercase letters showed that the relative inhibition rates of Congo red, $\mathrm{NaCl}$ and $\mathrm{H}_{2} \mathrm{O}_{2}$ on the mycelial growth of different strains were significantly different $(p \leq 0.01)$. 


\subsubsection{The Results of Complementation Test of Ctf1 $\beta$ Knockout}

The knockout complement fusion fragments KanMx-Ctf1 $\beta$ 1-up/KanMx + Ctf1 $\beta$ 1dowm and KanMx-Ctf1 $\beta$ 2-up/KanMx-Ctf1 $\beta$ 2-down were successfully constructed by the improved split-marker method. After the fusion fragment was transferred into the protoplast, it was cultured in TB3 medium for 3 days. A single colony was transferred to a PDA plate with a geneticin concentration of $100 \mu \mathrm{g} / \mathrm{mL}$, and several transformants were obtained after 4 days of culture. Then, the "Ctf1 $\beta 1$ ", "KanMx-Ctf1 $\beta 1$ " and "KanMxCtf1 $\beta$ 1-up" fragments of the mutant strain and Ctf1 $\beta 1$ complement mutant strains were detected by PCR, as shown in Figure S8. The sequencing results were consistent with the KanMx gene sequence.

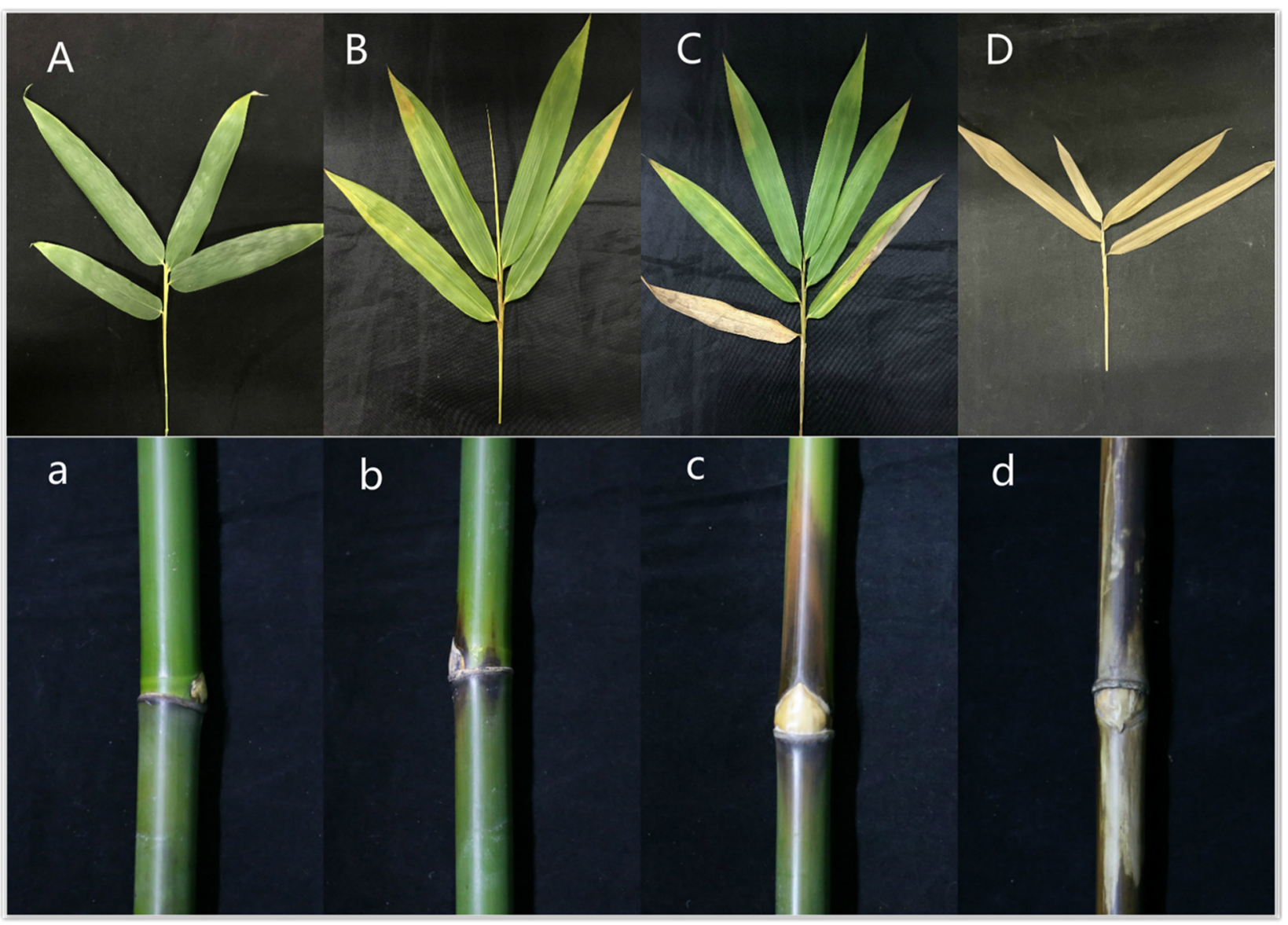

Figure 13. Symptoms of branches and leaves of plants infected with sterile water, $\triangle \mathrm{ApCtf1} \beta 1$ and $\Delta \mathrm{ApCtf1} \beta 2$ and wild-type strains after 25 days. Note: $(\mathbf{A}, \mathbf{a})$ are the symptoms of $B$. pervariabilis $\times D$. grandis leaves and branches inoculated with sterile water for 25 days, respectively. $(\mathbf{B}, \mathbf{b})$ are the symptoms of $B$. pervariabilis $\times D$. grandis leaves and branches inoculated with $\triangle$ ApCtf1 $\beta 1$ strain for 25 days, respectively. $(\mathbf{C}, \mathbf{c})$ are the symptoms of $B$. pervariabilis $\times D$. grandis leaves and branches inoculated with $\triangle \mathrm{ApCtf1} \beta 2$ strain for 25 days, respectively. $(\mathbf{D}, \mathbf{d})$ are the symptoms of $B$. pervariabilis $\times D$. grandis leaves and branches inoculated with wild type strain for 25 days, respectively.

\subsection{Phenotypic Analysis and Pathogenicity Detection of Complementary Strains}

There was no significant difference in phenotype between the two knockout complementary strains and the wild-type strain, and their sensitivity to oxidative stress of $\mathrm{H}_{2} \mathrm{O}_{2}$, tolerance to Congo red and salt tolerance to $\mathrm{NaCl}$ were similar (Figure 15). At the same time, the virulences of the two knockout complementary strains were consistent with the virulence of the wild-type, which was significantly enhanced compared with the mutant strain (Figure 16). 


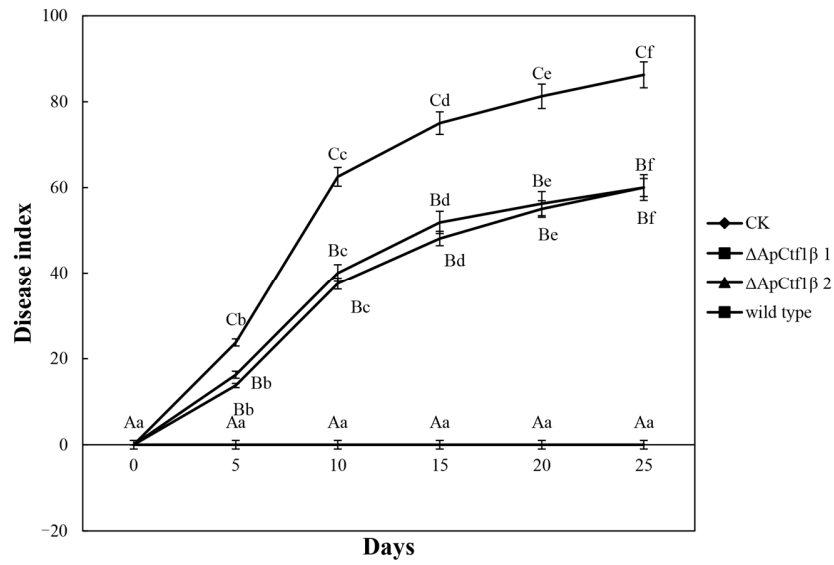

Figure 14. Dynamic changes in the disease index of $B$. pervariabilis $\times D$. grandis. infected by different strains. Note: $\mathrm{CK}, \triangle \mathrm{ApCtf1} \beta 1, \triangle \mathrm{ApCtf1} \beta 2$ and wild type represent the changes in the disease index of $B$. pervariabilis $\times D$. grandis. inoculated with sterile deionized water, $C t f 1 \beta 1$ deletion mutant, $C t f 1 \beta 2$ deletion mutant and wild-type $A$. phaeospermum, respectively. All assays were repeated three times, the data were analyzed using one-way ANOVA and Duncan's range test in SPSS 16.0. Different capital letters indicate that the disease index of different strains in the same period is significantly different, and different lowercase letters indicate that the disease index of the same strain in different periods is significantly different $(p \leq 0.01)$.

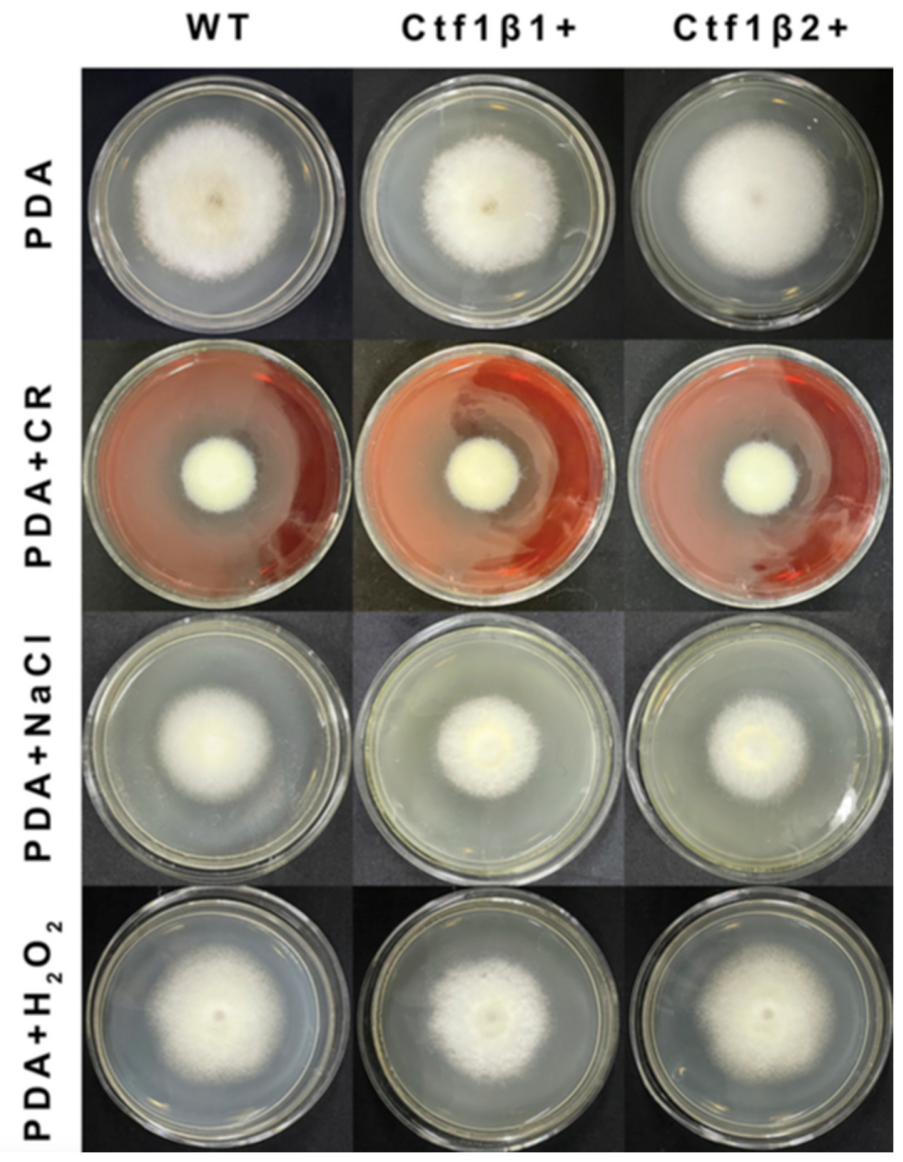

Figure 15. Comparison of phenotypic tolerance of the wild-type, $\mathrm{Ctf} 1 \beta 1$ complemented strain and $\mathrm{Ctf} 1 \beta 2$ complemented strain. Note: Wild-type, $\mathrm{Ctf1} \beta 1$ complemented strain and $\mathrm{Ctf} 1 \beta 2$ complemented strain were inoculated on PDA media or PDA media appended with various stressors and cultured at $25^{\circ} \mathrm{C}$ in darkness for 5 days. 


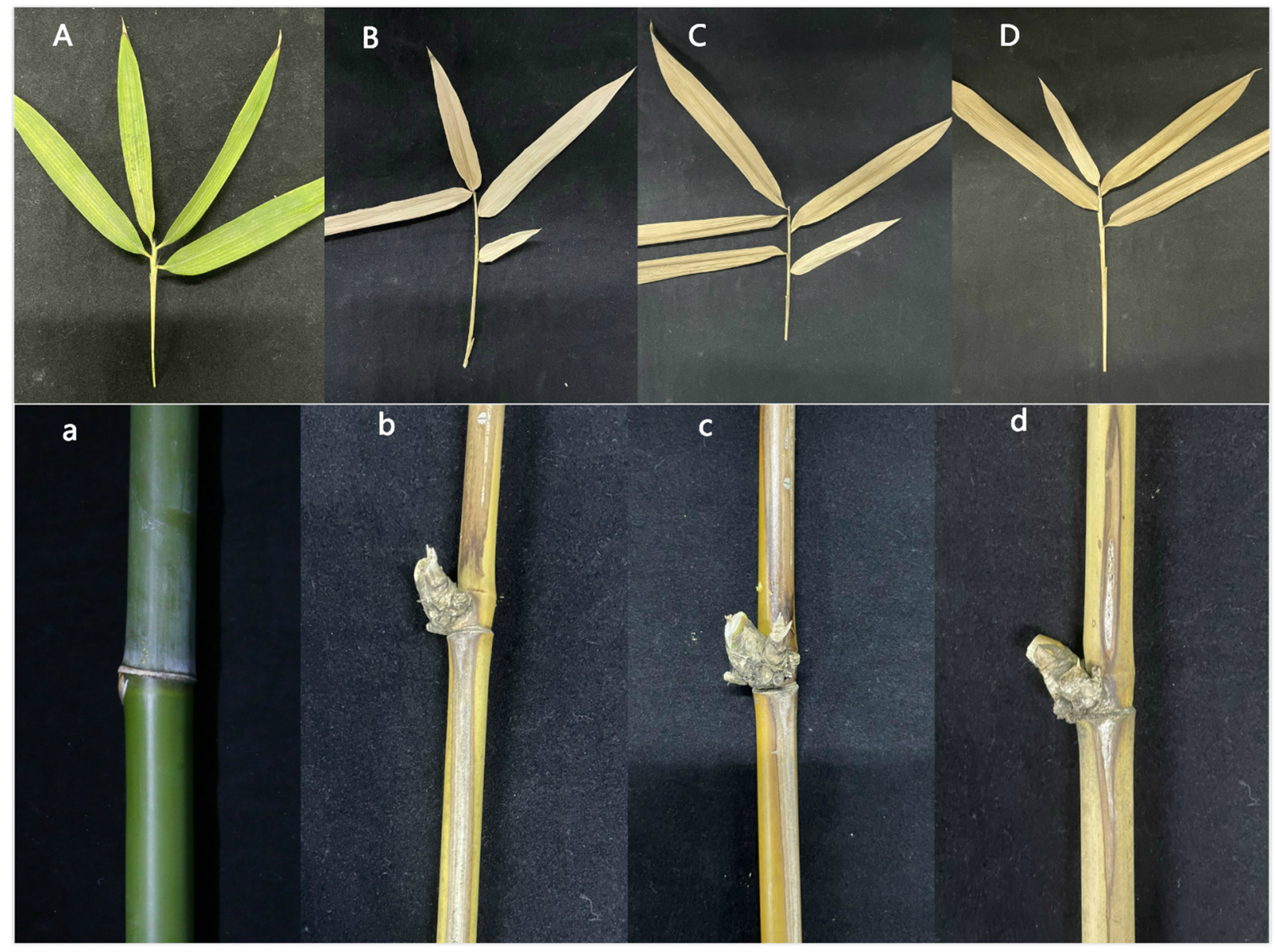

Figure 16. Symptoms of branches and leaves of plants infected with sterile water, $\mathrm{Ctf} 1 \beta 1$ complemented strain, $\mathrm{Ctf} 1 \beta 2$ complemented strain and wild-type strains after 25 days. Note: $(\mathbf{A}, \mathbf{a})$ are the symptoms of $B$. pervariabilis $\times D$. grandis leaves and branches inoculated with sterile water for 25 days, respectively. $(\mathbf{B}, \mathbf{b})$ are the symptoms of B. pervariabilis $\times$ D. grandis leaves and branches inoculated with Ctf1 $\beta 1$ complemented strain for 25 days, respectively. (C,c) are the symptoms of B. pervariabilis $\times D$. grandis leaves and branches inoculated with Ctf1 $\beta 2$ complemented strain for 25 days, respectively. $(\mathbf{D}, \mathbf{d})$ are the symptoms of $B$. pervariabilis $\times D$. grandis leaves and branches inoculated with wild type strain for 25 days, respectively.

\section{Discussion}

Transcriptome sequencing data have become an integral component of modern genetics, genomics and evolutionary biology [51]. In this study, A. phaeospermum cultured on PDA medium, PDA medium containing rice and PDA medium containing $B$. pervariabilis $\times D$. grandis. were sequenced by RNA-Seq. The results showed that the gene expression of pathogenic fungi was different among the three culture conditions. Similarly, transcriptome sequencing has been used to analyze the differential gene of the deformed mycelia, sclerotia and fruiting body in Ophiocordyceps sinensis [52], the differential gene of Colletotrichum gloeosporioides during the appressoria, quiescent and necrotrophic stages after infecting tomatoes [53], and the differential gene of Magnaporthe oryzae during spore germination and appressorium formation [54]. The genes encoding protein degradation and amino acid metabolism were significantly upregulated during the formation of the appressorium, while the expression of genes involved in protein synthesis was significantly decreased. In addition to genetic genes, the function and development process of organisms, the external environment is also one of the important factors affecting the growth and development of organisms and physiological functions. In the dynamic analysis of the transcriptome of maize seedlings under drought stress, the potential components of the 
abscisic acid signaling pathway were found to be significantly different between the two lines under drought stress [55]. Assembly analysis of the root transcriptome of Taxodium yasuensis under salt stress showed that there were 7959 differentially expressed genes under salt stress and nonsalt stress [56]. Therefore, during the growth and development of A. phaeospermum in different environments, the expression of genes closely related to the environment must be different. Compared with the fungus cultured on PDA medium and PDA medium containing nonhost plant rice, the expression of pathogenicity-related genes in the fungus cultured on PDA medium containing host plant B. pervariabilis $\times D$. grandis. may be increased.

GO annotation analyses suggest that various metabolic relationships played a role under different culture conditions. Compared with fungi cultured on PDA, the differentially upregulated genes of pathogenic fungi cultured on B. pervariabilis $\times D$. grandis. were involved mainly in cell biosynthesis, mitosis, nucleotide metabolism, organelle, cytoplasm and membrane formation, as well as translation factor activity, transmembrane transporter activity and hydrolase activity. KEGG pathway analysis suggested that the differentially upregulated genes were involved mainly in ribosome, endoplasmic reticulum protein processing, signal transduction of plant-pathogenic microorganism interaction, phosphoinositol signaling system, nitrogen metabolism, amino acid substitution thyme and metabolism of unsaturated fatty acids. It is intriguing that signal transduction in plant-pathogen interactions is a complex and necessary process in pathogen infection. From the beginning of contact recognition to the end of the susceptibility reaction, there are various signal transduction processes [57-59]. The differentially expressed genes were significantly enriched in the signal transduction pathway of plant-pathogenic microorganism interactions and the phosphoinositol signaling pathway. We speculated that the enriched genes in these two signaling pathways played an important role in the pathogenesis of $B$. pervariabilis $\times D$. grandis.

The functional annotation showed that these differentially expressed genes included mainly the glycoside hydrolase family, secreted hydrolase, cutinase transcription Factor 1 beta and secreted hydrolase. Previous studies have found that the attachment of pathogenic fungi on the surface of host plants, the formation of infection structures, the penetration of host plants and colonization in host plants are the four key steps to establish pathogenicity. Pathogenic fungi infect host plants mainly by attaching to their surfaces through spores and germ tubes as a prerequisite [60-63]. This process occurs mainly through fungal enzymes secreted by pathogenic fungi to change the degree of plant surface adhesion to make it adhere. Gramineae B. pervariabilis $\times D$. grandis. branches are composed mainly of cellulose and covered by cuticles, so the degrading cuticle, cellulose and cell wall of pathogens are usually closely related to pathogenicity $[64,65]$. The glycoside hydrolase family of hydrolases contains a variety of enzymes that are critical for lignocellulose degradation, which can degrade cellulose and hemicellulose, destroy plant cell walls and prevent lignification [36,66-68]. In addition to differentially expressed genes related to pathology, differentially expressed genes related to secondary metabolite synthesis were also significantly enriched. Some secondary metabolites of pathogenic fungi are toxic and pathogenic, of which mycotoxins are a major pathogenic factor in plant diseases [69]. For example, the secondary metabolite toxin of Fusarium oxysporum could cause cucumber fusarium wilt [70]. Penicillium rosenbergii produces a highly toxic secondary metabolite, PR toxin, which is a well-known isoprene mycotoxin [71]. Aflatoxin, a secondary metabolite of Aspergillus flavus, could cause many plant diseases, such as those of peanut, soybean and maize [72]. Therefore, the genes encoding hydrolase, lipase, toxic secondary metabolites and cutinase transcription factors among these differential genes were considered related to the pathogenicity of pathogens.

In this study, we observed that the symptoms of plant disease were different between wild-type and mutant strains by knocking out the $C \operatorname{tf} 1 \beta 1$ and $C t f 1 \beta 2$ genes. At the same time, a knockout complementation experiment ruled out epigenetic changes caused by the mutagenicity of protoplast transformation itself. This result indicates that the virulence of 
the mutant strains $\triangle \mathrm{APCtf1} \beta 1$ and $\triangle \mathrm{APCtf1} \beta 2$ was lower than the virulence of wild-type $A$. phaeospermum to a certain extent. We speculate that the $C t f 1 \beta$ gene may be related to virulence. This speculation is inconsistent with the conclusion that the $\operatorname{Ctf} 1 \beta$ gene in the plant pathogen Fusarium oxysporum is not necessary for virulence. We speculate that the pathogen F. oxysporum is a soil-borne pathogen that enters the host plant mainly through the root lacking cuticle without breaking through the cuticle barrier on the plant surface [73]. However, the host plant of $A$. phaeospermum is a kind of $B$. pervariabilis $\times D$. grandis with a thick/well-developed cuticle, which is a lipid layer on the outer surface of the cell wall of the plant surface and is divided into cuticle and wax [74]. In addition to the barrier function of water conservation and cleaning, it also has the complex defense function of promoting the overall development of plants and regulating the interaction between plants and pathogens [75-77]. To invade B. pervariabilis $\times D$. grandis, the plant pathogen $A$. phaeospermum must secrete cuticle-degrading enzymes, including esterase, cutinase and lipase, which can catalyze the hydrolysis of ester bonds of lipoprotein, fat and wax to penetrate the outermost cuticle barrier of the host [78,79]. Cutinase is considered an important enzyme for fungi to penetrate the cuticle and infect plants. Cutinase plays an important role in attaching to the plant epidermis, cuticle invasion and signal generation. In addition to cutinase, secretory lipase is also a virulence factor of pathogenic fungi $[80,81]$. Ctf1 was found to be the transcriptional activator of cutinase and lipase genes. An F. oxysporum strain lacking the function of the Ctf1 gene was impaired in the induction of cutinase activity and the prediction of gene expression of cutinase and lipase, but the virulence of Ctf1 to root pathogens was not necessary. However, Ctf1 $\alpha$ of Fusarium solani F sp. pisi is a functional homologous gene of $C t f 1$ that can control the expression of the cutinase gene and its own virulence. Although the pathogenicity of F. solani F sp. pisi was eliminated by $C t f 1 \alpha$, cutinase supplementation did not restore pathogenicity, which indicated that Ctf1 $\alpha$ was involved in the regulation of other genes necessary for pathogenicity [82]. From the amino acid sequence, $C t f 1 \alpha$ and $C t f 1 \beta$ have high homology with the proteins Fara and Farb of Aspergillus nidulans, and they also regulate the expression of genes related to lipid metabolism [83]. The outbreak of reactive oxygen species (ROS) in host plants is an important strategy for plants to inhibit pathogen infection. ROS are innate immune signals that can synthesize lignin and other phenolic polymers to block pathogen infection or act as second messengers to induce the expression of various plant defense-related genes and PAMP-triggered immunity (PTI) [84-88]. In this study, the loss of $C t f 1 \beta 1$ and $C t f 1 \beta 2$ gene function significantly increased the sensitivity of pathogens to extracellular oxidative stress (exposure to hydrogen peroxide). Ctf1 $\beta 1$ and $C \operatorname{tf1} \beta 2$ have been proven to play an important role in the detoxification of reactive oxygen species (ROS). This result is consistent with the conclusion that the BbCtf1 $\alpha$ and BbCtf1 $\beta$ deletion mutants of entomopathogenic Beauveria bassiana and the ccsge1 deletion mutants of the plant pathogen Cytospora chrysosperma are more sensitive to hydrogen peroxide [83,89]. The results showed that $C t f 1 \beta 1$ and $C t f 1 \beta 2$ were essential for oxidative stress and could inhibit the plant immune response. In addition, the loss of $C t f 1 \beta 1$ and $C \operatorname{tf} 1 \beta 2$ gene function leads to the increased sensitivity of pathogens to cell wall disturbance stress (exposure to Congo red), consistent with the change in stress response sensitivity caused by the deletion of the $B b C t f 1$ $\alpha$ and BbCtf1 $\beta$ genes in B. bassiana [83]. These results demonstrate that $C t f 1 \beta$ is crucial in maintaining cell wall integrity.

Supplementary Materials: The following are available online at https:/ / www.mdpi.com/article / $10.3390 /$ jof7121001/s1, Table S1. Results of transcriptome data alignment to A. phaeospermum genome. Table S2. Differential genes between CK-vs-T1. Table S3. Differential genes between CK-vs-T2. Table S4. Differential genes between T1-vs-T2. Figure S1. Illustration of the construction process of knockout out complementary vector. Figure S2. Test results of sequence assembly quality. Figure S3. The kill curve for hygromycin. Figure S4. The kill curve for genomycin. Figure S5. Results of knockout vector $C t f 1 \beta 1$ and $C t f 1 \beta 2$ construction. Figure S6. Detection of marker genes and target genes of the wild-type and mutant strains. Figure S7. Detection of marker genes and target genes of 
the wild-type and mutant strains. Figure S8. Detection of marker genes and target genes of mutant and complementary strains.

Author Contributions: Conceptualization, X.F. and P.Y.; Methodology, X.F.; Software, X.F.; Validation, S.L.; T.Z. and S.H.; Formal Analysis, X.F. and P.Y.; Investigation, T.Q. and P.Y.; Resources, T.L. and M.G.; Data Curation, T.Q. and M.G.; Writing-Original Draft Preparation, X.F.; Writing-Review \& Editing, S.L. and T.L.; Visualization, P.Y.; Supervision, S.H.; Project Administration, T.Z.; Funding Acquisition, S.L. All authors have read and agreed to the published version of the manuscript.

Funding: This research was funded by the National Natural Science Foundation of China, grant number 32171795, National Natural Science Foundation of China, grant number 31700568 and General Program of Science and Technology Department of Sichuan, grant number 2020YJ0400. The funder is Shujiang Li.

Institutional Review Board Statement: Not applicable.

Informed Consent Statement: Not applicable.

Data Availability Statement: The raw sequence reads for this study were deposited into the NCBI Sequence Reads Archive (SRA) under the accession numbers SRR9278662, SRR9278661, SRR9278664, SRR9278663, SRR9278658, SRR9278657, SRR9278660, SRR9278659, SRR9278665. The assembled contigs has been published in the NCBI Transcriptome Shotgun Assembly (TSA) under the accession number GHWG00000000.

Conflicts of Interest: The authors declare there is no conflict of interest.

\section{References}

1. Yang, Q. Research Status of B. pervariabilis $\times$ D. Daii and Cost-benefit analysis. J. Shandong For. Sci. Technol. 2007, 3, 101-103.

2. Zhao, M.R.; Huang, J.D.; Yao, J.P.; Li, F.L.; Zhang, X.L. Introduction effect of Bambusa ervariabilis $\times$ Dendrocalamopsis daii in dry hot valley of Huaning. For. Investig. Plan. 2004, 29, $24-26$.

3. Li, S.J.; Tang, Y.W.; Fang, X.M.; Qiao, T.M.; Han, S.; Zhu, T.H. Whole-genome sequence of Arthrinium phaeospermum, a globally distributed pathogenic fungus. Genomics 2020, 112, 919-929. [CrossRef] [PubMed]

4. Zhu, T.H.; Huang, Z.C.; Gao, Q.Z. Pathogen and occurrence regularity of Bambusa ervariabilis $\times$ Dendrocalamopsis daii blight. Forest Pest Dis. 2009, 28, 10-12.

5. Khan, K.R.; Sullia, S.B. Arthrinium phaeospermium var. indicum var. nov., a new market pathogen of cowpea, garden pea and french bean. Acta Bot. Indica 1980, 8, 103-104.

6. Liu, X.J.; Luo, X.Y.; Li, X.F.; Chen, Q.T. Taxonomic determination of toxigenic Arthrinium strains isolated from poisoning sugarcane. Mycosystema 1988, 7, 221-225.

7. Xia, L.M.; Zhang, S.X.; Huang, J.H.; Zhang, W.M. Studies on Arthrinium phaeospermum causing moso bamboo foot rot. J. Nanjing Fores. Univ. 1995, 19, 1-7.

8. Ma, G.L.; Hu, G.L.; Yu, C.Z.; Wu, J.L.; Xu, B.C. Phyllostachys prominens plum shoot wilt pathogenic fungoid and its biological characteristics. Zhejiang For. Coll 2003, 20, 44-48.

9. Piccolo, S.L.; Mondello, V.; Giambra, S.; Conigliaro, G.; Torta, L.; Burruano, S. Arthrinium phaeospermum, Phoma cladoniicola and Ulocladium consortiale, New Olive Pathogens in Italy. J. Phytopathol. 2014, 162, 258-263. [CrossRef]

10. Li, B.J.; Liu, P.Q.; Jiang, Y.; Weng, Q.Y.; Chen, Q.H. First Report of Culm Rot Caused by Arthrinium phaeospermum on Phyllostachys viridis in China. Plant Dis. 2016, 100, 10-13. [CrossRef]

11. Li, S.J.; Qiao, T.M.; Han, S.; Zhu, T.H.; Che, G.N. Effects of Protein Toxin from Arthrinium phaeospermum on Biophysical Characteristic and Respiration of Bambusa pervariabilis $\times$ Dendrocalamopsis grandis Mitochondria. Sci. Silvae Sin. 2014, 50, 119-125.

12. Li, S.J.; Zhu, T.H. Purification of the toxin protein PC from Arthrinium phaeospermum and its effect on the defence enzymes of Bambusa pervariabilis $\times$ Dendrocalamopsis grandis varieties. For. Pathol. 2013, 44, 96-106. [CrossRef]

13. Vijayakumar, E.K.S.; Roy, K.; Chatterjee, S.; Deshmukh, S.K.; Ganguli, B.N.; Fehlhaber, H.W.; Kogler, H. Arthrichitin. A new cell wall active metabolite from Arthrinium phaeospermum. J. Org. Chem. 1996, 61, 6591-6593. [CrossRef] [PubMed]

14. Bloor, S. Arthrinic acid, a novel antifungal polyhydroxyacid from Arthrinium phaeospermum. J. Antibiot. 2008, 61, 515-517. [CrossRef] [PubMed]

15. Li, S.J.; Zhu, T.H. Purification of the toxic protein from Arthrinium phaeospermum and its pathogenicity. Sci. Silvae Sin. 2012, 48, 144-149. [CrossRef]

16. Li, S.J.; Zhu, T.H.; Zhu, H.M.Y.; Liang, M.; Qiao, T.M.; Han, S.; Che, G. Purification of protein AP-Toxin from Arthrinium phaeospermum causing blight in Bambusa pervariabilis $\times$ Dendrocalamopisis grandis and its metabolic effects on four bamboo varieties. Phytopathology 2013, 103, 135-145. [CrossRef]

17. Qiao, T.M.; Zhu, T.H.; Li, S.J. Colonization of Pseudomonas aeruginosa ZB27 and its control effect on hybrid bamboo blight. Acta Phytophylacica Sin. 2011, 38, 133-138. [CrossRef] 
18. Li, S.J.; Fang, X.M.; Han, S.; Zhu, T.H.; Zhu, H.M.Y. Differential proteome analysis of hybrid Bamboo (Bambusa pervariabilis $\times$ Dendrocalamopsis grandis) under fungal stress (Arthrinium phaeospermum). Sci. Rep. 2019, 9, 18681. [CrossRef]

19. Peng, Q.; Fang, X.M.; Zong, X.Z.; He, Q.Q.; Zhu, T.H.; Han, S.; Li, S.J. Comparative transcriptome analysis of Bambusa pervariabilis $\times$ Dendrocalamopsis grandis against Arthrinium phaeospermum under protein AP-toxin induction. Gene 2020, 725, 144-160. [CrossRef]

20. He, Q.Q.; Fang, X.M.; Zhu, T.H.; Han, S.; Zhu, H.M.Y.; Li, S.J. Differential Proteomics Based on TMT and PRM Reveal the Resistance Response of Bambusa pervariabilis $\times$ Dendrocalamopisis grandis Induced by AP-Toxin. Metabolites 2019, 9, 166. [CrossRef]

21. Ranf, S. Sensing of molecular patterns through cell surface immune receptors. Curr. Opin. Plant Biol. 2007, 38, 68-77. [CrossRef] [PubMed]

22. Dangl, J.L.; Horvath, D.A.A.; Staskawicz, B. Pivoting the plant immune system from dissection to deployment. Science 2013, 341, 746-751. [CrossRef]

23. Jones, J.D.G.; Dang, J.L. The Plant immune system. Nature 2006, 444, 323-329. [CrossRef] [PubMed]

24. Mentlak, T.A.; Kombrink, A.; Shinya, T.; Ryder, L.S.; Otomo, I.; Saitoh, H.; Terauchi, R.; Nishizawa, Y.; Shibuya, N.; Thomma, B.P.H.J.; et al. Effector-mediated suppression of chitin-triggered immunity by Magnaporthe oryzae is necessary for rice blast disease. Plant Cell 2012, 24, 322-335. [CrossRef] [PubMed]

25. Tian, L.; Shi, S.; Nasir, F. Comparative analysis of the root transcriptomes of cultivated and wild rice varieties in response to Magnaporthe oryzae infection revealed both common and species-specific pathogen responses. Rice 2018, 11, 26. [CrossRef] [PubMed]

26. Windram, O.; Madhou, P.; McHattie, S. Arabidopsis defense against Botrytis cinerea: Chronology and regulation deciphered by high-resolution temporal transcriptomic analysis. Plant Cell 2012, 24, 3530-3557. [CrossRef]

27. Smith, J.E.; Mengesha, B.; Tang, H.; Mengiste, T.; Bluhm, B.H. Resistance to Botrytis cinerea in Solanum lycopersicoides involves widespread transcriptional reprogramming. BMC Genom. 2014, 15, 334. [CrossRef]

28. Luo, Z.B.; Li, Y.J.; Mousa, J.; Bruner, S.; Zhang, Y.G.; Pei, Y.; Keyhani, N.O. B bmsn2 acts as a pH dependent negative regulator of secondary metabolite production in the entomopathogenic fungus Beauveria bassiana. Environ. Microbiol. 2015, 17, 1189-1202. [CrossRef]

29. Yamamoto, T.; Tsunematsu, Y.; Noguchi, H.; Hotta, K.; Watanabe, K. Elucidation of pyranonigrin biosynthetic pathway reveals a mode of tetramic acid, fused $\gamma$-pyrone, and exo-methylene formation. Org. Lett. 2015, 17, 4992-4995. [CrossRef]

30. Fan, L.L.; Fu, K.H.; Yu, C.J.; Li, Y.Y.; Li, Y.Q.; Chen, J. Thc6 protein, isolated from Trichoderma harzianum, can induce maize defense response against Curvularia lunata. J. Basic. Microb. 2015, 55, 591-600. [CrossRef]

31. Fang, Z.D. Plant Disease Research Methods, 3rd ed; China Agricultural Press: Beijing, China, 1998; pp. $26-27$.

32. Andrade, A.E.; Silva, L.P.; Pereira, J.L.; Noronha, E.F.; Reis, J.F.B.; Bloch, C., Jr.; Dos Santos, M.F.; Domont, G.B.; Franco, O.L.; Mehta, A. In vivo proteome analysis of Xanthomonas campestris pv. campestris in the interaction with the host plant Brassica oleracea. FEMS Microbiol. Lett. 2008, 281, 167-174. [CrossRef]

33. Jiang, H.; Jiang, M.G.; Wang, L.K.; Yao, P.Y.; Ma, L.; Wang, C.T.; Wang, H.; Qiao, G.L.; Hu, B.S.; Fan, J.Q. The Ribosomal Protein RplY Is Required for Pectobacterium carotovorum Virulence and Is Induced by Zantedeschia elliotiana Extract. Phytopahtology 2017, 107, 1322-1330. [CrossRef] [PubMed]

34. Chomczynski, P.; Sacchi, N. Single-step method of RNA isolation by acid guanidinium thiocyanate-phenol-chloroform extraction. Anal. Biochem. 1987, 162, 156-169. [CrossRef]

35. Vogel, H.; Wheat, C.W. Accessing the transcriptome: How to normalize mRNA Pools. Methods Mol. Biol. 2011, 772, 105. [CrossRef] [PubMed]

36. Khalyfa, A.; Chlon, T.; Maoqiang, H. Microarray reveals complement components are regulated in the serum-deprived rat retinal ganglion cell line. Mol. Vis. 2007, 13, 293-308. [CrossRef]

37. Yang, H.; Shi, P.J.; Liu, Y.; Xia, W.; Wang, X.; Cao, H.; Ma, R.; Luo, H.; Bai, Y.; Yao, B. Loop 3 of fungal endoglucanases of glycoside hydrolase family 12 modulates catalytic efficiency. Appl. Environ. Microb. 2016, 83, e03123-16. [CrossRef]

38. Grabherr, M.G.; Haas, B.J.; Yassour, M.; Levin, J.Z.; Thompson, D.A.; Amit, I. Full-length transcriptome assembly from RNA-Seq data without a reference genome. Nat. Biotechnol. 2011, 29, 644-652. [CrossRef]

39. Altschul, S.F.; Madden, T.L.; Schäffer, A.A.; Zhang, J.H.; Zhang, Z.; Miller, W.; Lipman, D.J. Gapped blasta and PSI blast: A new generation of protein database search programs. Nucleic Acids Res. 1997, 25, 3389-3402. [CrossRef]

40. Ashburner, M.; Ball, C.A.; Blake, J.A.; Botstein, D.; Butler, H.; Cherry, J.M.; Davis, A.A.; Dolinski, K.; Dwight, S.S.; Eppig, J.T.; et al. Gene ontology: Tool for the unification of biology. Nat. Genet. 2000, 25, 25-29. [CrossRef]

41. Kanehisa, M.; Goto, S.; Kawashima, S.; Okuno, Y.; Hattori, M. The KEGG resource for deciphering the genome. Nucleic Acids Res. 2004, 32, 277-280. [CrossRef]

42. Koonin, E.V.; Fedorova, N.D.; Jackson, J.D.; Jacobset, A.R.; Krylov, D.M.; Makarova, K.S.; Mazumder, R.; Mekhedov, S.L.; Nikolskaya, A.N.; Rao, B.S.; et al. A comprehensive evolutionary classification of proteins encoded in complete eukaryotic genomes. Genome Biol. 2004, 5, R7. [CrossRef]

43. Deng, Y.Y.; Li, J.Q.; Wu, S.F.; Zhu, Y.P.; Zhu, Y.P.; Chen, Y.W.; He, F. Integrated nr database in protein annotation system and its localization. Comp. Eng. 2006, 32, 71-74. [CrossRef]

44. Apweiler, R.; Bairoch, A.; Wu, C.H.; Barker, W.C.; Boeckmann, B.; Ferro, S.; Gasteiger, E.; Huang, H.; Lopez, R.; Magrane, M.; et al. UniProt: The universal protein knowledgebase. Nucleic Acids Res. 2004, 32, 115-119. [CrossRef] [PubMed] 
45. Conesa, A.; Gotz, S.; Garcia-Gomez, S.; Terol, J.; Talon, M.; Robles, M. Blast2GO: A universal tool for annotation, visualization and analysis in functional genomics research. Bioinformatics 2005, 21, 3674-3686. [CrossRef]

46. Ye, J.; Fang, L.; Zheng, H.K.; Zheng, Y.; Chen, J.; Zhang, Z.J.; Wang, J.; Li, S.; Li, R.; Bolund, L.; et al. WEGO: A web tool for plotting GO annotations. Nucleic Acids Res. 2006, 34, W293-7. [CrossRef]

47. Li, B.; Dewey, C. RSEM: Accurate transcript quantification from RNA-Seq data with or without a reference genome. BMC Bioinform. 2011, 12, 323. [CrossRef]

48. Livak, K.J.; Schmittgen, T.D. Analysis of relative gene expression data usingreal-time quantitative PCR and the 2- $\Delta \Delta \mathrm{Ct}$ method. Methods 2001, 25, 402-408. [CrossRef]

49. Goswami, R.S. Targeted gene replacement in fungi using a Split-Marker approach. Methods Mol. Biol. 2011, 255-269. [CrossRef]

50. Luo, F.Y.; Fang, X.M.; Liu, H.; Zhu, T.H.; Han, S.; Peng, Q.; Li, S.J. Differential transcriptome analysis and identification of genes related to resistance to blight in three varieties of Bambusa pervariabilis $\times$ Dendrocalamopsis grandis. PeerJ 2021, 9, e12301. [CrossRef]

51. Logacheva, M.D.; Kasianov, A.S.; Binogradov, D.V.; Samigullin, T.H.; Penin, A.A. De novo sequencing and characterization of floral transcriptome in two species of buckwheat (Fagopyrum). BMC Genom. 2011, 12, 30. [CrossRef]

52. Zhong, X.; Gu, L.; Wang, H.Z.; Lian, D.H.; Zheng, Y.M.; Zhou, S.; Liu, X. Profile of Ophiocordyceps sinensis transcriptome and differentially expressed genes in three different mycelia, Sclerotium and fruiting body developmental stages. Fungal Biol. 2018, 122, 943-951. [CrossRef] [PubMed]

53. Alkan, N.; Friedlander, G.; Ment, D.; Prusky, D.; Fluhr, R. Simultaneous transcriptome analysis of Colletotrichum gloeosporioides, and tomato fruit pathosystem reveals novel fungal pathogenicity and fruit defense strategies. New. Phytol. 2015, 205. [CrossRef]

54. Oh, Y.; Donofrio, N.M.; Pan, H.; Coughlan, S.J.; Brown, D.E.; Meng, S.W.; Mitchell, T.; Dean, R.A. Transcriptome analysis reveals new insight into appressorium formation and function in the rice blast fungus Magnaporthe oryzae. Genome Biol. 2008,9 , R85. [CrossRef] [PubMed]

55. Zheng, J.; Fu, J.J.; Gou, M.Y.; Huai, J.L.; Liu, Y.J.; Jian, M.; Huang, Q.; Guo, X.; Dong, Z.; Wang, H.; et al. Genome-wide transcriptome analysis of two maize inbred lines under drought stress. Plant Mol. Biol. 2010, 72, 407-421. [CrossRef] [PubMed]

56. Yu, C.; Sheng, X.; Yin, Y. Transcriptome analysis of the Taxodium 'Zhongshanshan 405' roots in response to salinity stress. Plant Physiol. Biochem. 2016, 100, 156-165. [CrossRef]

57. Blumwald, E.; Aharon, G.S.; Lam, B.C.H. Early signal transduction pathways in plant-pathogen interactions. Trends Plant Sci. 1998, 3, 342-346. [CrossRef]

58. Fang, X.P.; Chen, W.Y.; Ma, H.S.; Yu, H.; Wang, S.Z.; Xin, Y. Research progress in plant-pathogen responsive proteins. J. Nuclear Agric. Sci. 2014, 28, 825-832. [CrossRef]

59. Vlot, A.C.; Klessig, D.F.; Park, S.W. Systemic acquired resistance: The elusive signal(s). Curr. Opin. Plant Biol. 2008, 11, 436-442. [CrossRef]

60. Braun, E.J.; Howard, R.J. Adhesion of fungal spores and germlings to host plant surfaces. Protoplasma 1994, 181, $202-212$. [CrossRef]

61. Momany, M.; Talbot, N.J. Septins focus cellular growth for host infection by pathogenic fungi. Front. Cell Dev. Biol. 2017, 5. [CrossRef]

62. Nicholson, R.L.; Epstein, L. Adhesion of fungi to the plant surface: Prerequisite for pathogenesis. Fungal Spore Dis. Initiat. Plants Anim. 1991, 3-23. [CrossRef]

63. Schafer, W. Molecular mechanisms of fungal pathogenicity to plants. Annu. Rev. Phytopathol. 1994, 32, 461-477. [CrossRef]

64. Kolattukudy, P.E. Enzymatic penetration of the plant cuticle by fungal pathogens. Annu. Rev. Plant Physiol. 1985, 23, 223-250. [CrossRef]

65. Pascholati, S.F.; Deising, H.; Leiti, B.; Anderson, D. Cutinase and non-specific esterase activities in the conidial mucilage of Colletotrichum graminicola. Physiol. Mol. Plant Pathol. 1993, 42, 37-51. [CrossRef]

66. Harris, P.V.; Welner, D.; Mcfarland, K.C.; Re, E.; Poulsen, J.C.N.; Brown, K.; Salbo, R.; Ding, H.; Vlasenko, E.; Merino, S.; et al. Stimulation of lignocellulosic biomass hydrolysis by proteins of glycoside hydrolase Family 61: Structure and function of a large, Enigmatic Family. Biochemistry 2010, 49, 3305-3316. [CrossRef]

67. Xu, Z.W.; Escamilla-Trevino, L.L.; Zeng, L.H.; Lalgondar, M.; Bevan, D.R.; Winkel, B.S.J.; Mohamed, A.; Cheng, C.; Shih, M.; Poulton, J.; et al. Functional genomic analysis of Arabidopsis thalianaglycoside hydrolase family 1. Plant Mol. Biol. 2004, 55, 343-367. [CrossRef]

68. Zhou, P.; Liu, Y.; Yan, Q.; Chen, Z.; Qin, Z.; Jiang, Z. Structural insights into the substrate specificity and transglycosylation activity of a fungal glycoside hydrolase family $5 \beta$-mannosidase. Acta Crystallogr. Sect. D Biol. Crystallogr. 2014, 70, 2970-2982. [CrossRef]

69. Waring, P.; Newcombe, N.; Edel, M.; Qin, H.L.; Hui, J.; Sjaarda, A. Cellular uptake and release of the immunomodulating fungal toxin gliotoxin. Toxicon 1994, 32, 491-504. [CrossRef]

70. Zhou, J.Y.; Wang, N.; Sun, Y.M.; Gu, Z.C.; Wang, R.R.; Saydin, A.; Shen, Q.; Guo, S. Nitrate increased cucumber tolerance to Fusarium wilt by regulating fungal toxin production and distribution. Toxins 2017, 9, 100. [CrossRef]

71. Hidalgo, P.I.; Poirier, E.; Ullan, R.V.; Piqueras, J.; Meslet-Cladiere, L.; Coton, E.; Coton, M. Penicillium rueforti PR toxin gene cluster characterization. Appl. Microbiol. Biotechnol. 2017, 101, 2043-2056. [CrossRef] [PubMed]

72. Dutton, M.F. Fungal toxin. Nature 1970, 225, 1171. [CrossRef]

73. Rocha, A.L.M.; Pietro, A.D.; Ruiz-Roldan, C.; Roncero, M.I.G. Ctf1, a transcriptional activator of cutinase and lipase genes in Fusarium oxysporum is dispensable for virulence. Mol. Plant Pathol. 2008, 9, 293-304. [CrossRef] 
74. Nawrath, C. Unraveling the complex network of cuticular structure and function. Curr. Opin. Plant Biol. $2006,9,281-287$. [CrossRef] [PubMed]

75. Barthlott, W.; Neinhuis, C. Purity of the sacred lotus, or escape from contamination in biological surfaces. Planta 1997, $202,1-8$. [CrossRef]

76. Serrano, M.; Coluccia, F.; Torres, M.; L'Haridon, F.; Métraux, J. The cuticle and plant defense to pathogens. Front. Plant Sci. 2014, 5, 274. [CrossRef]

77. Voisin, D.; Nawrath, C.; Kurdyukov, S.; Franke, R.B.; Reina-Pinto, J.J.; Efremova, N.; Will, I.; Schreiber, L.; Yephremov, A. Dissection of the complex phenotype in cuticular mutants of Arabidopsis reveals a role of SERRATE as a mediator. PLoS Genet. 2009, 5, e1000703. [CrossRef]

78. Ortiz-Urquiza, A.; Keyhani, N.O. Action on the surface: Entomopathogenic fungi versus the insect cuticle. Insects 2013, 4, 357-374. [CrossRef]

79. Silva, W.O.B.D.; Santi, L.; Correa, A.P.F.; Silva, L.A.D.; Bresciani, F.R.; Schrank, A.; Vainstein, M.H. The entomopathogen Metarhizium anisopliae can modulate the secretion of lipolytic enzymes in response to different substrates including components of arthropod cuticle. Fungal Biol. 2010, 114, 911-916. [CrossRef] [PubMed]

80. Rogers, L.M.; Flaishman, M.A.; Kolattukudy, P.E. Cutinase Gene Disruption in Fusarium solanif sp pisi Decreases Its Virulenceon Pea. Plant Cell 1994, 6, 935-945. [CrossRef]

81. Voigt, C.A.; Schafer, W.; Salomon, S. A secreted lipase of Fusarium graminearum is a virulence factor required for infection of cereals. Plant J. 2005, 42, 364-375. [CrossRef]

82. Li, D.X.; Sirakova, T.; Rogers, L.; Ettinger, W.F.; Kolattukudy, P.E. Regulation of Constitutively Expressed and Induced Cutinase Genes by Different Zinc Finger Transcription Factors in Fusarium solani f. sp. pisi (Nectria haematococca). J. Biol. Chem. 2002, 227, 7905-7912. [CrossRef] [PubMed]

83. Wang, Z.L.; Pan, H.B.; Huang, J.; Yu, X.P. The zinc finger transcription factors Bbctf1 $\alpha$ and Bbctf1 $\beta$ regulate the expression of genes involved in lipid degradation and contribute to stress tolerance and virulence in a fungal insect pathogen. Pest Manag. Sci. 2020, 76, 2589-2600. [CrossRef]

84. Gan, Y.Z.; Zhang, L.S.; Zhang, Z.G.; Dong, S.M.; Li, J.; Wang, Y.; Zheng, X. The LCB 2 subunit of the sphingolip biosynthesis enzyme serine palmitoyltransferase can function as an attenuator of the hypersensitive response and Bax-induced cell death. New Phytol. 2009, 181, 127-146. [CrossRef] [PubMed]

85. Torres, M.A.; Dangl, J.L. Functions of the respiratory burst oxidase in biotic interactions, abiotic stress and development. Curr. Opin. Plant Biol. 2005, 8, 397-403. [CrossRef]

86. L'Haridon, F.; Besson-Bard, A.; Binda, M.; Serrano, M.; Abou-Mansour, E.; Balet, F.; Schoonbeek, H.; Hess, S.; Mir, R.; Léon, J.; et al. A Permeable Cuticle Is Associated with the Release of Reactive Oxygen Species and Induction of Innate Immunity. PLoS Pathog. 2011, 7, e1002148. [CrossRef] [PubMed]

87. Torres, M.A.; Jones, J.D.; Dangl, J.L. Pathogen-induced, NADPH oxidase-derived reactive oxygen intermediates suppress spread of cell death in Arabidopsis thaliana. Nat. Genet. 2005, 37, 1130-1134. [CrossRef]

88. Zhang, H.J.; Fang, Q.; Zhang, Z.G.; Wang, Y.C.; Zheng, X.B. The role of respiratory burst oxidase homologues in elicitor-induced stomatal closure and hypersensitive response in Nicotiana benthamiana. J. Exp. Bot. 2009, 60, 3109-3122. [CrossRef] [PubMed]

89. Han, Z.; Yu, R.; Xiong, D.G.; Tian, C.M. A Sge1 homolog in Cytospora chrysosperma governs conidiation, virulence and the expression of putative effectors. Gene 2021, 778, 145474. [CrossRef] 